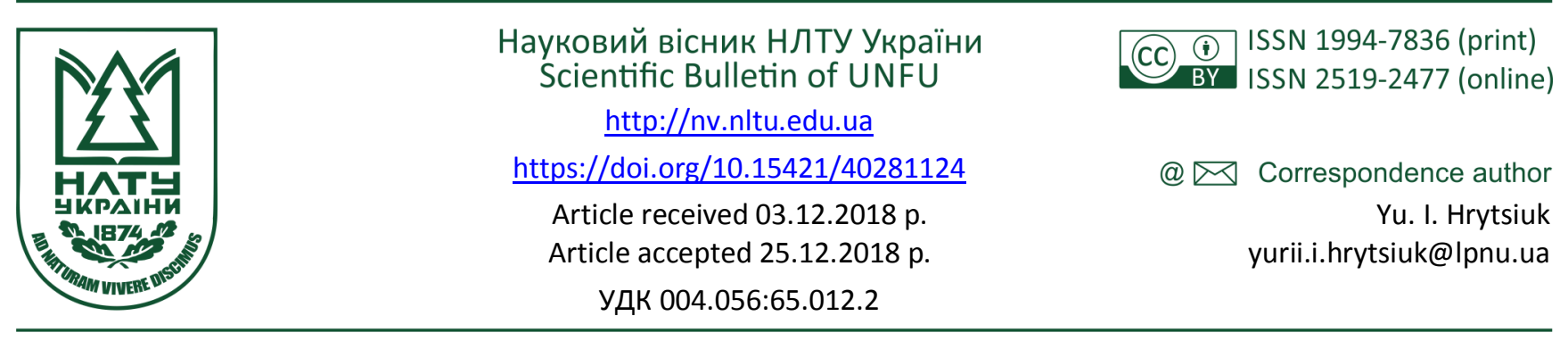

Ю. І. Грицюк, В. С. Далявський

Національний університет "Львівська політехніка", м. Львів, Україна

\title{
ФОРМАЛІЗАЦІЯ ПРОЦЕСУ УПРАВЛІННЯ РИЗИКАМИ РОЗРОБЛЕННЯ ПРОГРАМНОГО ЗАБЕЗПЕЧЕННЯ
}

Розроблено підхід до формалізації процесу управляння ризиками розроблення програмного забезпечення (ПЗ), який дає змогу ідентифікувати та оцінити несприятливі ситуацій під час реалізації етапів програмного проекту, а також уможливлює розроблення стратегій і тактик їх передбачення, сприйняття та подолання негативних наслідків від їх прояву. 3'ясовано, що управління ризиками розроблення ПЗ потрібно розглядати як процес, який дає змогу визначити особливості такого управління, основні категорії наявних ризиків, ризик-орієнтовний підхід до управління ними. Уточнено підходи до ідентифікації ризиків розроблення ПЗ, їхнього грунтовного аналізу, планування та моніторингу, що дало змогу поміняти модель діяльності проектного менеджменту загалом і змінити модель поведінки керівника проекту зокрема на різних етапах реалізації програмного проекту. Удосконалено методику визначення можливих джерел появи ризиків розроблення ПЗ й ідентифікації потенційних ризикових подій, сформовано структуровану множину наявних ризиків реалізації програмних проектів і розроблено їх формалізовані моделі для проведення відповідних розрахунків.

Розроблено методику визначення ймовірностей настання потенційних ризикових подій у відповідних їх множинах, запропоновано підхід до розподілу вартості реалізації програмного проекту за цими множинами загалом і потенційними ризиковими подіями зокрема, визначено частки та величини можливих збитків від настання ризикових подій, встановлено пріоритети їх пом'якшення та ранжування. Уточнено заходи із запобігання чи знешкодження ризиків розроблення ПЗ, удосконалено методику визначення ймовірності зменшення або усунення різних ризикових подій, визначено правила і політику реалізації програмного проекту, розроблено їх формалізовані моделі.

Ключові слова: програмне забезпечення; ризикові події; негативні наслідки; потенційні проблеми; ймовірність настання несприятливих подій; прийнятний (допустимий) ризик; ризик виникнення потенційних небезпек.

Вступ. В інженерії програмного забезпечення (ПЗ) існують ризики його розроблення незалежно від того, як проект його реалізації був підкріплений фінансово i матеріально-технічним забезпеченням, нормативно-правовими актами і професійною підтримкою його виконавців. Зазвичай, під ризиком в інженерії ПЗ розуміють ситуацію, яка може призвести до втрати очікуваного прибутку, або подію, яка може поставити під загрозу успіх реалізації програмного проекту (Sommervill, 2002; Braude, 2004; DoD. USA, 2014). Управління ризиками невід'ємна складова ефективного управління будь-яким програмним проектом, керівник якого повинен ефективно планувати, управляти та здійснювати постійний контроль за всіма етапами виконання завдань проекту (Johnson \& Tennessee, 2006; Singaevskaia, 2008). Керівник проекту має вміти прогнозувати потенційні прибутки від успішної реалізації проекту та оцінювати можливі втрати від прийняття необгрунтованих рішень, а також прагнути до зменшення збитків при настанні ризикованих подій (Williams, Pandelios \& Behrens, 1999).

На сьогодні більшість IT-компанії, зазвичай, стають конкурентоспроможними тільки за рахунок інновацій- ної діяльності, яка за своєю сутністю пов'язана з різними ризиками, тобто ймовірністю виникнення збитків або недоотримання прибутків порівняно 3 прогнозованими (Williams, Pandelios \& Behrens, 1999; Zyl, 2010). Тому ризик $\epsilon$ одночасно як причиною можливих збитків, так і джерелом потенційних прибутків (Borisov, Krumberg \& Fedorov, 1990). Також ризик - важлива складова процесу управління, неврахування якого призводить до вироблення, аналізу й прийняття необгрунтованих і малоефективних управлінських рішень (Hrytsiuk \& Zhabych, 2018; Zhabych \& Hrytsiuk, 2018). Основне завдання управління ризиками - не відмовитись від ризику як такого взагалі, а приймати ризикові рішення, грунтуючись на об'єктивних критеріях і допустимих втратах (Sheptur \& Hrytsiuk, 2018). Прийняті керівником проекту ризик-орієнтовані рішення часто приводять до більш ефективної реалізації програмних проектів, від яких отримують свою вигоду як замовники i розробники ПЗ, так і його безпосередні користувачі.

Аналітичні дослідження та спостереження, виконані провідними зарубіжними експертами протягом останнього десятиліття (Ostrovyj, Krasovskyj \& Grybynchuk,

Інформація про авторів:

Грицюк Юрій Іванович, д-р техн. наук, професор, кафедра програмного забезпечення. Email: yurii.i.hrytsiuk@Ipnu.ua; https://orcid.org/0000-0001-8183-3466; ResearcherID: V-3995-2017

Далявський Владистав Сергійович, студент, кафедра програмного забезпечення. Email: mobivlad@outlook.com

Цитування за ДстУ: Грицюк Ю. І., Далявський В. С. Формалізація процесу управління ризиками розроблення програмного забезпечення. Науковий вісник НлтУ України. 2018, т. 28, № 11. С. 135-153.

Citation APA: Hrytsiuk, Yu. I., \& Dalyavskyy, V. S. (2018). Formalization of the Risk Management Process of Software Development. Scientific Bulletin of UNFU, 28(11), 135-153. https://doi.org/10.15421/40281124 
2015), давали не дуже обнадійливі результати щодо вирішення проблеми управління ризиками розроблення П3. Незважаючи на бурхливий розвиток різних технологій програмування, проте ще й на сьогодні відома значна частина програмних проектів, які не прийнято вважати повністю успішними (CHAOS Manifesto, 2013; Bloch, Blumberg \& Laartz, 2012; Alferov, 2008). Під успішною реалізацією програмного проекту надалі будемо розуміти вчасне його виконання у встановлені терміни в межах виділеного бюджету та $з$ реалізацією всіх замовлених функціональних можливостей майбутнього П3 (рис. 1).

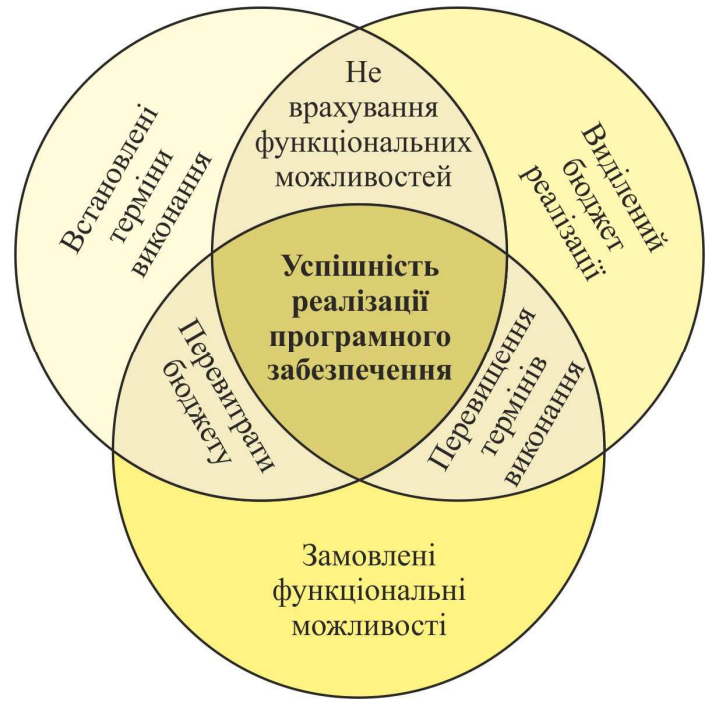

Рис. 1. Візуалізація поняття "успішна реалізація програмного проекту"

Управління ризиками реалізації програмного проекту безпосередньо пов'язане $з$ такими проблемами як управління процесом розроблення ПЗ, управління вимогами до ПЗ та проблемою планування ризик-менеджменту, тобто управління страховим ризиком (DeMarko \& Lister, 2005). Для досягнення бажаних результатів у встановлені терміни та в допустимих межах фінансових і матеріальних витрат етапи реалізації програмного проекту потрібно ретельно й досконало планувати та якісно ними управляти, виходячи з наявних ресурсів, у т.ч. й людських можливостей.

Невід'ємною складовою процесу управління ризиками розроблення ПЗ є моніторинг (Ustenko, 2003), який передбачає: розроблення та реалізацію процедур контролю за поточними ризиками реалізації програмного проекту; оцінювання та контроль за ризиками і ризикменеджментом; переоцінювання ризиків і розроблення коригувальних антиризикових заходів щодо зменшення чи усунення різних ризикових подій.

Отже, процес розроблення ПЗ не завжди завершується успішно і часто пов'язаний із ризиками недостатньої функціональності ПЗ, із невиконанням термінів реалізації програмного проекту або з перевищенням виділеного бюджету. Тому актуальним завданням наразі $\epsilon$ формалізація процесу управління ризиками розроблення ПЗ, результати якого мають характеризувати можливі негативні наслідки від їх прояву, а також прогнозувати збитки від подальшого їх поширення. Завдання керівництва компанії-розробника ПЗ зводиться до скорочення кількості таких ризиків і зменшення витрат на їх ліквідацію. Зниження ризиків реалізації програмного проекту сприяє підвищенню якості ПЗ, ефектив- ності та результативності його виконання, а також потенційних прибутків IT-компанії.

Аналіз останніх досліджень та публікацій. Проблеми розроблення ПЗ в різний час були розглянуті в багатьох наукових публікаціях вітчизняними і закордонними ученими, такими як С. Іванько (Ivanko, 2008), К. Кастеллані (Kastellani, 1982), В. Ковальов (Kovalev, n.d.), В. Шквір (Shkvir, Zahorodnii \& Vysochan, 2007) тощо. Проте, у своїх дослідженнях і публікаціях вони мало приділяли уваги аналізу причин появи ризиків, які необхідно враховувати у процесі розроблення ПЗ.

Питання управління ризиками розроблення ПЗ широко розглянуто в різних наукових джерелах, починаючи 3 нормативних документів Міністерства оборони США (Williams, Pandelios \& Behrens, 1999), в роботах, написаних з використанням їхніх даних (Johnson \& Tennessee, 2006), і завершуючи виданнями для широкого загалу (DeMarko \& Lister, 2005). Наприклад, в роботах (DoD. USA, 2014; Johnson \& Tennessee, 2006; Williams, Pandelios \& Behrens, 1999) процес організації ризик-менеджменту розглянуто як проект всередині програмного проекту. Автори стверджують, що цей проект має свої етапи життєвого циклу і управління ним потрібно проводити паралельно $з$ управлінням програмним проектом. У роботі (DeMarko \& Lister, 2005) хоча матеріал і викладено дещо спрощено, проте його головна ідея ризик-менеджмент складна, але необхідна складова життєвого циклу будь-якого програмного проекту.

Оскільки джерела (DoD. USA, 2014; Johnson \& Tennessee, 2006; Williams, Pandelios \& Behrens, 1999; DeMarko \& Lister, 2005) - закордонні, то вони мало пристосовані для вирішення проблем розроблення ПЗ в Україні. Також в усіх цих дослідженнях не було враховано економічних і локальних особливостей процесу розроблення ПЗ компаніями, які знаходяться в Україні. Хоча в роботі (Johnson \& Tennessee, 2006) й розглянуто спрощену модель управління ризиками розроблення програмного проекту, однак описані в інших роботах деякі методології управління ризиками не розглядають їх як інструмент для побудови адекватних моделей ризиків розроблення ПЗ.

Отже, управління ризиками розроблення ПЗ є достатньо дискусійною темою, тому особливості реалізації цього процесу широко відображено в багатьох наукових дослідженнях (Kulikova, 2008; Lipaev, 2005; Maksimov \& Nikonov, 2004) і закордонних (Heckerman, 1995; SWEBOK, 2004; DeMarko \& Lister, 2005). Ці публікації призначені для різних дослідників - як для професіоналів 3 ризик-менеджменту та розроблення ПЗ (Heckerman, 1995; SWEBOK, 2004), так і для широкого загалу (DeMarko \& Lister, 2005; Kulikova, 2008; Sobol, 1972; Sommervill, 2002).

Наприклад, в роботах (Kulikova, 2008; Lipaev, 2005) наведено кількісний аналіз ризиків у контексті управління ними. Водночас, у роботі (Lipaev, 2005) зосереджено увагу на особливостях аналізу ризиків і зменшення їх кількості під час реалізації проектів складних програмних систем. Також в ній досліджено моделі та процеси організації ризик-менеджменту у великому проекті розроблення ПЗ.

Існують різні моделі управління ризиками (Braude, 2004; Zyl, 2010; Sommervill, 2002; Terekhov, 2003), ceред яких найбільшого використання набула модель Інституту програмної інженерії Карнеги-Меллона (англ. 
Software Engineering Institute, SEI), що містить як вимоги стандартів (ISO/IEC 12207, 2008; ISO/IEC 33001, 2015), так і відомі кращі практичні рекомендації щодо їх запобігання чи знешкодження. Наприклад, в роботах (Kulikova, 2008; Sobol, 1972) розглянуто теоретичні основи імітаційного моделювання та створення відповідних моделей на базі методу Монте-Карло. В роботах (Borisov, Krumberg \& Fedorov, 1990; Leonenkov, 2003) розглянуто теоретичні основи апарату нечіткої логіки, а в роботах (Heckerman, 1995; Hugin Expert, n.d.; Terekhov, 2003) наведено теоретичні основи Байєсівської мережі довіри (БМД) та приклади їх використання.

Однак, незважаючи на наявні теоретичні та практичні напрацювання в сфері управління ризиками розроблення ПЗ, їх ефективному використанню в сфері управління програмними проектами за наявних українських реалій ведення бізнесу заважають деякі обставини. Насамперед це стосується стандартів, які розроблені закордонними організаціями та призначеними для застосування у великих IT-компаніях (ISO/IEC 12207, 2008; ISO/IEC 33001, 2015), досвідчені фахівці яких пройшли відповідну підготовку та володіють сучасними методами ризик-менеджменту (Mamedova, 2005; Mykhailovska, 2008). Також розробники цих стандартів, здебільшого, прямо вказують на те, що "ідентифікацію ризиків бізнес-діяльності організації, як правило, мають проводити незалежні експерти" (Grytsiuk \& Leshkevych, 2017). Тому вітчизняні ризик-орієнтовані IT-компанії потребують певної адаптації змісту цих документів до їхньої виробничої діяльності (Hrytsiuk \& Nemova, 2018).

Окрім цього, успішна реалізація програмних проектів вітчизняними ІТ-компаніями потребує грунтовних наукових розробок щодо вдосконалення методів і прийомів управління ризиками та їхнього детального аналізу (Hrytsiuk, 2018), які б спиралися на міжнародний досвід, а також враховували особливості кризових ситуацій в країні, що і становить актуальність цього дослідження.

Не претендуючи на значні здобутки у вирішенні багатьох проблем управління ризиками реалізації програмних проектів загалом, спробуємо внести і свою лепту у вирішення деяких питань інженерії ПЗ, особливо тих, які стосуються формалізації процесу управляння ризиками його розроблення. Тому, як на сьогодні, видається нам актуальним дослідження, яке стосується підготовки адекватної методики формалізації процесу управляння ризиками розроблення ПЗ, уточнення підходів до їх ідентифікації та аналізу, планування та моніторингу, що дасть змогу поміняти модель діяльності проектного менеджменту загалом і змінити модель поведінки керівника проекту зокрема на різних етапах реалізації програмного проекту.

Об'єкт дослідження - управляння ризиками розроблення ПЗ.

Предмет дослідження - методи та засоби формалізації процесу управляння ризиками розроблення ПЗ, які дають змогу визначити особливості такого управління, основні категорії ризиків, уточнити ризик-орієнтовний підхід до управління ними, а також уможливить визначення прийнятного рівня ризику для успішного завершення (провалу) програмного проекту.

Метою дослідження є підготовка адекватної методики формалізації процесу управляння ризиками роз- роблення ПЗ, яка дасть змогу оцінити несприятливі ситуацій під час реалізації етапів програмного проекту, а також уможливить розроблення стратегій і тактик їх передбачення, сприйняття та подолання негативних наслідків від їх прояву.

Для реалізації зазначеної мети потрібно виконати такі основні завдання дослідження:

1) вияснити, чому управління ризиками розроблення ПЗ потрібно розглядати як процес, який дасть змогу визначити особливості такого управління, основні категорії ризиків, ризик-орієнтовний підхід до управління ними;

2) деталізувати та формалізувати процес управління ризиками розроблення ПЗ, що дасть змогу оцінити несприятливі ситуацій під час реалізації етапів програмного проекту, уможливить розроблення стратегій і тактик їх передбачення та сприйняття, локалізацію та ліквідацію;

3) уточнити підходи до ідентифікації ризиків розроблення ПЗ, їхнього аналізу, планування та моніторингу, що дасть змогу поміняти модель діяльності проектного менеджменту загалом і змінити модель поведінки керівника проекту зокрема на різних етапах реалізації програмного проекту;

4) удосконалити методики визначення можливих джерел появи ризиків й ідентифікації потенційних ризикових подій, що дасть змогу виявити деяку кількість невідомих ризиків реалізації програмного проекту та розробити їх формалізовані моделі для проведення відповідних розрахунків;

5) удосконалити методику визначення ймовірностей настання потенційних ризикових подій у відповідних їх множинах, запропонувати підхід до розподілу вартості реалізації програмного проекту за цими множинами загалом і потенційними ризиковими подіями зокрема, визначити частки та величини можливих збитків від настання ризикових подій, встановити пріоритети їх пом'якшення та ранжування;

6) уточнити заходи із запобігання чи знешкодження ризиків розроблення ПЗ, удосконалити методику визначення ймовірності зменшення або усунення різних ризикових подій, що дасть змогу визначити правила і політику реалізації програмного проекту, здійснити управління ризиками розроблення ПЗ, а також уможливить розроблення їх формалізованих моделей;

7) уточнити поняття "моніторинг ризиків розроблення П3", встановити особливості його реалізації в ІТ-компанії з організаційної точки зору, що дасть змогу визначити його як систему 3 певним набором таких елементів, як мета, об'єкт, суб'єкт і механізм реалізації;

8) зробити відповідні висновки та надати рекомендації щодо використання розробленої методики формалізації процесу управляння ризиками розроблення ПЗ.

1. Управління ризиками розроблення ПЗ як процес. Зазвичай, в інженерії ПЗ під ризиками розуміють появу негативних ситуацій ймовірнісного характеру, які істотно впливають на результати реалізації програмного проекту, відображають втрати або збитки від недостатньої якості виконуваних процедур чи завдань проекту. Ці втрати та збитки викликані неточностями при формуванні наборів вимог до П3 (Hrytsiuk, 2018), недоліками обгрунтування термінів і бюджету проекту, невиявленими дефектами на етапах конструювання ПЗ та тестування його компонент, а також під час неправильної його експлуатації (Alferov, 2008; Braude, 2004; Fatrell, Shafer \& Shafer, 2003; Sommervill, 2002; Zyl, 2010). Тут важливо розуміти, що ризик - це ймовірна подія, яка може відбутися з різними наслідками, а може 
й оминути від напасти програмний проект чи навіть продукти його реалізації.

Ризики виникнення потенційних загроз і небезпек існують практично в усіх програмних проектах, але не завжди вони відбуваються та наносять шкоду ПЗ (Zhabych \& Hrytsiuk, 2018). Зазвичай, проявлена небезпека перетворюється на проблему як поточну, так i майбутню. Прогнозування потенційних загроз і небезпек у багатьох випадках - це передбачення прояву деяких ризикових подій, що, як правило, мають негативно вплинути на хід реалізації програмного проекту та на його остаточні результати - продукти проекту. У такому контексті ризик виникнення потенційної небезпеки розглядають як прояв деякої випадкової події, яка має ймовірнісний характер (Kulikova, 2008).

Хоча ризики розроблення ПЗ й поділено на декілька основних категорій (Kuzminykh, Khaustov \& Korostelov, 2010), однак, у кожному конкретному випадку можуть бути додані й інші типи ризиків, які не розглянуто у цьому дослідженні. Отже, до основних категорій ризиків належать:

- ризики, пов'язані з неповнотою вимог до ПЗ, тобто передбачають врахування очевидних і реалізацію другорядних вимог, а також неврахування критичних і відкладання концептуальних вимог тощо;

- технологічні ризики, пов'язані з незнанням технологій, які заплановано використовувати персоналом для розроблення П3, або з низькою апробацією й відпрацьованістю цих технології в колективі виконавців проекту;

- ризики, пов'язані з низькою кваліфікацією персоналу, тобто керівник проекту повинен знати можливості своїх працівників i, за потреби, організувати їх навчання ще до початку реалізації програмного проекту, щоб не витрачати час на ліквідацію помилок у вже розробленому ПЗ;

- політичні ризики - саботаж, який, зазвичай, не виставляють напоказ, проте може занапастити будь-який проект, якщо його учасники матимуть свої цілі діяльності, які не завжди збігатимуться з цілями керівника проекту.

- Згідно з класифікацією ризиків розроблення ПЗ за характером наслідків, ризики можна розділити на дві групи - чисті та спекулятивні (Alferov, 2008; Braude, 2004; Fatrell, Shafer \& Shafer, 2003). Особливість чистих ризиків полягає в тому, що вони, як правило, несуть тільки втрати від підприємницької діяльності, а спекулятивні (комерційні) ризики призводять до фінансових і матеріальних втрат, або надають можливість IT-компанії отримати додаткові прибутки.

- Чисті ризики розроблення ПЗ можна поділити на ризики проектного управління, проектні, кадрові та делікатні, які, водночас, також допускають власну класифікацію, а саме:

- ризики поганої взаємодії між замовником ПЗ і його виконавцеем, пов'язані з відсутністю комунікації між їхніми керівниками або їх представниками. Недостатнє обговорення користувацьких вимог до ПЗ або його архітектури може негативно позначитися на його майбутньому функціоналі та, як наслідок, на якість самого ПЗ;

- ризики неефективного управління програмним проектом, пов'язані з відсутністю навиків проектного менеджменту в керівника проекту, а також з відсутністю інтересу або мотивації у нього для успішної його реалізації;

- ризики недостатньої обізнаності керівника проекту про поточний його стан, пов'язані з відсутністю прямого і зворотного зв'язку під час виконання завдань проекту. Вони виникають тоді, коли керівник проекту не вибудував робочий процес так, щоб контролювати хід виконання завдань проекту на всіх етапах його реалізації;

- ризики неефективного планування етапів реалізації проек$m y$ - можуть бути пов'язані з відсутністю навиків планування процесу виконання завдань проекту як його керівником, так і їх виконавцями, якщо вони готують інформацію про терміни виконання багатьох робіт і завдань проекту;

- ризики недостатності системи контролю за реалізацією завдань проекту - обумовлені значною кількістю особливостей у області проектного менеджменту при розробленні П3, коли складно передбачити і врахувати всі можливі ситуації, які можуть виникнути під час реалізації станів програмного проекту;

- ризики появи нових користувацьких вимог до ПЗ - виникають в процесі його розроблення, коли у замовника з'являються все нові й нові вимоги, які відсувають терміни виконання конкретних завдань проекту і затрудняють можливість оцінювати їх виконання;

- ризики наявних суперечностей у вимогах до ПЗ, пов'язані 3 виявленням суперечностей у вимогах замовника на етапі декомпозиції користувацьких вимог у системні вимоги, або на етапі конструювання програмного коду чи інтеграції продуктів проекту;

- ризики неправильно сформульованих системних вимог - виникають тоді, коли на самому початку реалізації проекту були некоректно сформульовані характеристики цільової системи, для якої розробляють ПЗ: програмне оточення (операційна система, встановлені компоненти, сервіси i т.п.) або вимоги до апаратної частини (частота процесора, об'єм жорсткого диска, обсяг оперативної пам'яті і т.п.);

- ризики бажання використати нові технологї розроблення ПЗ, пов'язані з використанням нестабільних технологій, які ще не пройшли апробацію у виробничому процесі або під час виконання інших програмних проектів;

- ризики нездатності персоналу впоратися зі складністю розроблення ПЗ - виникають тоді, коли ПЗ може бути настільки складним, що команда його розробників просто не може з ним упоратися;

- ризики нездатності керівника проекту впоратися з труднощзами його реалізащії - виникають тоді, коли програмний проект може бути настільки складним, що команда його виконавців просто не може з ним упоратися;

- ризик низької продуктивності праці команди розробників П3 - обумовлені значною тривалістю реалізації етапів програмного проекту. Часто на самому початку реалізації проекту це призводить до значних втрат часу, який складно буде надолужити на наступних етапах його реалізації. При цьому доводиться або переносити терміни виконання завдань проекту, або працювати в більш динамічному режимі на дещо пізніх етапах реалізації проекту;

- ризик зміни працівників програмного проекту - виникають тоді, коли проект покидають ключові його виконавці, які максимально володіють інформацією щодо особливостей етапів його реалізації;

- ризики розкрадання продуктів проекту - виникають тоді, коли розробники ПЗ, йдучи з проекту, забирають з собою деякі його складові, що розроблялися ними, i, трохи модифікувавши їх, можуть продати або використовувати в інших проектах, наприклад, у конкурентів;

- ризики порушення закону про авторське право - виникають тоді, коли виконавці проекту використовують без відома його керівника чужі продукти проекту (програмні коди, алгоритми або бібліотеки тощо), які захищені законом про авторське право, але їх офіційно не було придбано або їх використання не узгоджене $з$ автором.

Спекулятивні ризики розроблення ПЗ можна поділити на ризики фінансових обмежень, ризики зміни кон'юнктури ринку, валютні ризики, а саме:

- ризики фінансових обмежень - можуть виникнути як 3 вини керівника проекту, який планував його терміни і бюджет реалізації, так і з інших причин, наприклад, низької платоспроможності замовника П3;

- ризики зміни кон'юнктури ринку - обумовлені зміною економічної ситуації, яка складалася на ринку вже після планування термінів і бюджету реалізації проекту. При цьому 
могли закладатися чинники, актуальні на момент планування, але їх зміна не була врахована;

- валютні ризики, пов'язані з можливим виникненням збитків або додаткових доходів внаслідок несприятливої або сприятливої зміни курсів валют, якщо компанія співпрацює 3 іноземними замовниками чи виконавцями проекту.

Однією із складових процесу управління програмним проектом є управління ризиками розроблення ПЗ на кожному етапі його реалізації. Загалом, управління ризиками - це: 1) процес прийняття управлінських рішень, їх реалізація та контроль за виконанням, спрямованих на зниження ймовірності появи несприятливих ситуацій та на мінімізацію можливих втрат, викликаних їх проявом; 2) набір систематичних процедур, пов'язаних 3 ідентифікацією ризиків, їхнім аналізом і прийняттям рішень щодо їх запобігання, локалізації чи знешкодження, які забезпечують мінімізацію негативних наслідків від виникнення ризикових подій, а також максимізацію ймовірності настання сприятливих подій та позитивного ефекту від них (Alferov, 2008; Zyl, 2010).

Отже, для підвищення ймовірності успішного завершення програмного проекту потрібне запровадження сучасних методів управління ризиками. Тут під управлінням ризиками розроблення ПЗ будемо розуміти виконання процедур ідентифікації та аналізу ризикових подій як запланованих, так і випадкових, а також аналізу наслідків від настання сприятливих подій і негативних ситуацій. При цьому ставиться за мету максимізувати ймовірність появи сприятливих подій та їхніх позитивних результатів і мінімізувати ймовірність настання несприятливих ситуацій i негативні наслідки іхнього прояву. Однак, досить часто керівники проектів обмежуються тільки роботою $з$ несприятливими ситуаціями, тобто потенційними небезпеками та негативними наслідками від їхнього прояву.

Управління ризиками розроблення ПЗ містить повне розуміння внутрішніх і зовнішніх чинників, які впливають на етапи реалізації програмного проекту, можуть призвести до негативних його наслідків. Аналіз потенційних ризиків виконують після формування плану реалізації програмного проекту (Hrytsiuk \& Zhabych, 2018). Головною метою управління ризиками $\epsilon$ їхня ідентифікація та контроль за чинниками, що рідко трапляються, однак часто призводять до значних втрат/збитків на поточному та подальших етапах реалізації програмного проекту.

Існують різні моделі управління ризиками розроблення П3 (Alferov, 2008; Braude, 2004; Fatrell, Shafer \& Shafer, 2003; Sommervill, 2002; Zyl, 2010), серед яких найбільшого використання набула модель SEI (англ. Software Engineering Institute), запропонована Інститутом програмної інженерії Карнеги-Меллона. Ця модель містить як вимоги стандартів (ISO/IEC 12207, 2008; ISO/IEC 33001, 2015) розроблення П3, так і відомі кращі практичні рекомендації щодо запобігання чи знешкодження ризиків реалізації програмного проекту. Хоча модель SEI й наведена у вигляді текстових рекомендацій та плану виконання дій, однак у ній відсутній формалізований метод управління ризиками, що призводить, зазвичай, до специфічного пii використання та вільного трактування отриманих результатів. Тому основним завданням цієї роботи є деталізація та формалізація процесу управління ризиками розроблення ПЗ.

2. Деталізація та формалізація процесу управління ризиками розроблення П3. В інженерії ПЗ управ- ління ризиками його розроблення - це процес оцінювання несприятливих ситуацій під час реалізації етапів програмного проекту, а також розроблення стратегій i тактик їх передбачення, сприйняття та подолання негативних наслідків від їх прояву. Основна мета процесу управління ризиками - це поміняти модель діяльності проектного менеджменту загалом і змінити модель поведінки керівника проекту зокрема на різних етапах його реалізації. Сутність таких змін полягає в тому, що замість реагування на несприятливі ситуації, що вже відбулися, необхідно проводити їх попередження та здійснювати опрацювання можливих сценаріїв виконання дій в разі настання ризикових подій. Це те, що називається бути активними (англ. be proactive) під час реалізації етапів програмного проекту.

Зниження ризику прийняття помилкових рішень керівником проекту можна досягнути за умови використання сучасних програмних засобів оброблення даних, візуалізації отриманих результатів у вигляді, зручному для швидкого сприйняття та ефективного аналізу, а також прогнозування розвитку ризикових подій, в т.ч. й негативних наслідків від них. Наявні на сьогодні можливості автоматизованих систем оброблення даних дають змогу бізнес-аналітикам формалізувати якісні та кількісні оцінки від професійних експертів і комплексно оцінити різноманітні ризикові події та негативні наслідки від їх прояву.

Як було зазначено вище, процес управління ризиками розроблення ПЗ зазвичай оцінюють 3 використанням моделі SEI, яка містить як вимоги стандартів (ISO/IEC), так і відомі кращі практичні рекомендації щодо запобігання, знешкодження чи ухиляння від ризиків реалізації програмного проекту. Таке оцінювання набуває особливого значення із розвитком і вдосконаленням сучасних технологій оброблення експертних даних (Morhun, 2011). Усе це потребує розроблення нових методів і засобів комплексного оцінювання потенційних ризикових подій, які б враховували як деякі невизначеності вхідної інформації, так і суб'єктивність оцінок професійних експертів.

Загалом, експертні технології - невід'ємна складова процесу прийняття управлінських рішень (DeMarco Tom, 2002) як при розробленні П3, при управлінні змінами вимог до нього та ризиками їх ефективної реалізаціï, так і під час управління якістю самого П3 (Botsula \& Morhun, 2014; Paulk \& Curtis, 2001). Прийняття рішень професійними експертами грунтується на достовірному поданні інформації про стан наявної ситуації, правильному розумінні суті наявної проблеми і точності характеристик іiі складових. Кожний експерт, який бере участь в процесі оцінювання ризиків розроблення ПЗ і від думки якого залежить остаточне рішення керівника проекту, повинен володіти необхідними знаннями в своїй предметній області, має мати певний досвід і навики роботи. За їх відсутності надані експертами оцінки можуть призвести до невиправних помилок і значних втрат - фінансових, матеріальних і часових (Hrytsiuk \& Buchkovska, 2017).

Запропонований у роботі (Ostrovyj, Krasovskyj \& Grybynchuk, 2015) підхід до управління ризиками розроблення ПЗ складається з таких основних етапів:

1) ідентифікація ризиків розроблення ПЗ;

2) аналіз ризиків розроблення ПЗ;

3) планування ризиків розроблення П3;

4) моніторинг ризиків розроблення ПЗ. 
Спробуємо дещо деталізувати зазначені етапи такого підходу та формалізуємо модель процесу управління ризиками розроблення ПЗ.

Eman 1. Ідентифікація ризиків розроблення ПЗ. Мета цього етапу - виявити деяку кількість невідомих ризиків реалізації програмного проекту. Зазвичай, потенційних проблем навколо будь-якого проекту надзвичайно багато, тому завдання зводиться до успішного їх попередження та виявлення, а також кількісного оцінювання можливих збитків від їх негативного прояву. На початку розроблення ПЗ варто передбачити та ідентифікувати від 50 до 100 ризикових подій чи несприятливих ситуацій, грунтовно їх проаналізувати та проранжувати в порядку пріоритету реагування на них, а в подальшому - звести їх перелік до 20-30 шт. у форматі "причина-ризик-ефект".

1.1. Визначення можливих джерел появи ризиків. Згідно з моделлю SEI, є значна кількість найбільш поширених джерел появи ризиків, які подамо у вигляді такої множини компонент:

$$
\boldsymbol{R S}=\left\{\tilde{T}^{R S}, \tilde{C}^{R S}, \tilde{P}^{R S}, \tilde{M}^{R S}\right\} .
$$

У цьому виразі введено позначення таких компонент і їх складових:

- $\tilde{T}^{R S}=\left\{t_{j}^{R S}, j=\overline{1, n_{1}^{R S}}\right\}, \tilde{T}^{R S} \subset \boldsymbol{R S}-$ множина джерел появи технічних ризиків, елементами якої $€: t_{1}^{R S}-$ функціональні характеристики П3; $t_{2}^{R S}$ - характеристики якості П3; $t_{3}^{R S}-$ характеристики надійності ПЗ; $t_{4}^{R S}$ - застосовність ПЗ; $t_{5}^{R S}$ - продуктивність ПЗ; $t_{6}^{R S}$ - супроводжуваність ПЗ; $t_{7}^{R S}$ повторне використання компонент ПЗ, де $n_{1}^{R S}=7$;

- $\tilde{C}^{R S}=\left\{c_{j}^{R S}, j=\overline{1, n_{2}^{R S}}\right\}, \tilde{C}^{R S} \subset \boldsymbol{R S}-$ множина джерел появи вартісних ризиків, елементами якої $є: c_{1}^{R S}$ - обмеження сумарного бюджету на реалізацію програмного проекту; $c_{2}^{R S}$ - недоступна вартість реалізації програмного проекту; $c_{3}^{R S}$ - недооцінювання можливих витрат на реалізацію програмного проекту, де $n_{2}^{R S}=3$;

- $\tilde{P}^{R S}=\left\{p_{j}^{R S}, j=\overline{1, n_{3}^{R S}}\right\}, \tilde{P}^{R S} \subset \boldsymbol{R S}$ - множина джерел появи планових ризиків, елементами якої $\epsilon: p_{1}^{R S}-$ можливості гнучкого внесення змін до планів процесу розроблення ПЗ; $p_{2}^{R S}$ - можливості порушення встановлених термінів етапів реалізації програмного проекту; $p_{3}^{R S}-$ не передбачення потреби внесення змін до планів процесу розроблення ПЗ; $p_{4}^{R S}-$ низький ступінь реалізму при встановленні термінів реалізації етапів програмного проекту, де $n_{3}^{R S}=4$;

- $\tilde{M}^{R S}=\left\{m_{j}^{R S}, j=\overline{1, n_{4}^{R S}}\right\}, \tilde{M}^{R S} \subset \boldsymbol{R} \boldsymbol{S}$ - множина джерел появи ризиків реалізації завдань управління програмним проектом, елементами якої $є: m_{1}^{R S}-$ хибна стратегія реалізації програмного проекту; $m_{2}^{R S}$ - неефективне планування етапів реалізації програмного проекту; $m_{3}^{R S}-$ неякісне оцінювання термінів реалізації етапів програмного проекту; $m_{4}^{R S}$ - прогалини в документуванні етапів реалізації програмного проекту; $m_{5}^{R S}$ - промахи в прогнозуванні результатів реалізації програмного проекту, де $n_{4}^{R S}=5$.

Аналіз специфікації вимог до ПЗ (SRS) дав змогу визначити такі компоненти джерел появи:

- технічних ризиків з ймовірністю $q_{1 j}^{R S}=t_{j}^{R S} \in[0 \ldots 1], j=\overline{1, n_{1}^{R S}}$;

- вартісних ризиків з ймовірністю $q_{2 j}^{R S}=c_{j}^{R S} \in[0 \ldots 1], j=1, n_{2}^{R S}$;

- планових ризиків з ймовірністю $q_{3 j}^{R S}=p_{j}^{R S} \in[0 \ldots 1], j=\overline{1, n_{3}^{R S}}$;
- ризиків реалізації завдань управління програмним проектом 3 ймовірністю $q_{4 j}^{R S}=m_{j}^{R S} \in[0 \ldots 1], j=\overline{1, n_{4}^{R S}}$.

3 врахуванням зазначеного вище сформуємо множину можливих джерел появи потенційних ризиків розроблення ПЗ, ймовірність визначення яких матиме такий вигляд

$$
\tilde{\tilde{Q}}^{R S}=\left\{\tilde{Q}_{i}^{R S}=\left\{q_{i j}^{R S} \in[0(0,01) 1], j=\overline{1, n_{i}^{R S}}\right\}, i=\overline{1, M^{R S}}\right\},
$$

де: $q_{i j}^{R S}$ - ймовірність визначення $j$-го джерела появи потенційного ризику з $i$-ої їх множини; $0(0,01) 1$ - діапазон значень ймовірностей визначення від 0 до 13 кроком 0,$01 ; n_{i}^{R S}$ - кількість джерел появи потенційних ризиків розроблення ПЗ у $i$-ій множині; $M^{R S}$ - кількість множин наявних джерел появи потенційних ризиків розроблення ПЗ.

Тоді формалізована модель визначення можливих джерел появи потенційних ризиків розроблення ПЗ відповідної множини має такий вигляд

$$
\tilde{G}^{R S}=\left\{g_{i}^{R S}=\frac{100}{N_{\Sigma}^{R S}} \sum_{j=1}^{n_{i}^{R S}} q_{i j}^{R S}, i=\overline{1, M^{R S}}\right\}, \%,
$$

а формалізована модель визначення сумарних джерел появи потенційних ризиків виглядатиме так

$$
G_{\Sigma}^{R S}=\sum_{i=1}^{M^{R S}} g_{i}^{R S}, \%,
$$

де: $g_{i}^{R S}$ - ймовірність визначення джерел появи потенційного ризику з $i$-ої їх множини; $N_{\Sigma}^{R S}-$ повна ймовірність визначення джерел появи потенційних ризиків розроблення ПЗ, визначаємо за такою формулою

$$
N_{\Sigma}^{R S}=\sum_{i=1}^{M^{R S}} n_{i}^{R S} .
$$

\begin{tabular}{|c|c|c|}
\hline 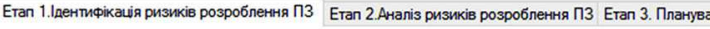 & ання риз & sиків розро \\
\hline 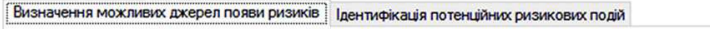 & & \\
\hline Мнохина дхерел появи техоічних ризиків & 4.09 & $22.72 \%$ \\
\hline функціональні характеристики ПЗ & 0.32 & \\
\hline характеристики якості ПЗ & 0.18 & \\
\hline характеристики нарійності П3 & 0.64 & \\
\hline застосовніicr ПЗ & 0.28 & \\
\hline часова продуктивність ПЗ & 0.93 & \\
\hline супроводжуваність ПЗ & 0.84 & \\
\hline повторне використання компонент ПЗ & 0.90 & \\
\hline Мнохина дкереп появи вартісних ризиків & 1.26 & $7.00 \%$ \\
\hline обмеження сумарного бюджепу на програмний проект & 0.66 & \\
\hline недоступна вартість реалізашї програмного проекту & 0.10 & \\
\hline низька ступінь реалізму при ошннюванні витрат на програмний проект & 0.50 & \\
\hline Мнохина дхерел появи планових ризиків & 2.03 & $11.28 \%$ \\
\hline властввості та мохливості гнучкості внесення змін до планів хиптевого циклу розроблення ПЗ & 0.99 & \\
\hline Можливості порушення встановпених термінів реапізаці етапів хиптевого циклу розроблення ПЗ & 0.87 & \\
\hline низька ступінь реалізму при встановленті планів і етапів життевого циклу розроблення ПЗ & 0.17 & \\
\hline Мнохина дкерел появи ризиків реалізациї процесу управління програмним проектом & 3.17 & $17.61 \%$ \\
\hline ммбна стратегія реалізашї програмного проекту & 0.89 & \\
\hline неефективне планування проекту розроблення ПЗ & 0.73 & \\
\hline неякісне ошннювання програмного проекту & 0.51 & \\
\hline прогапини в документуванні етапів реалізаці́ програмного проекту & 0.91 & \\
\hline промахи в прогнозуванні результатів реалізашіі програмного проекту & 0.13 & $58,61 \%$ \\
\hline
\end{tabular}

На рис. 2 наведено результати визначення можливих джерел появи потенційних ризиків розроблення ПЗ на підставі специфікації вимог до нього.

Рис. 2. Форма для визначення можливих джерел появи ризиків розроблення ПЗ

Отже, згідно з результатами аналізу специфікації вимог до ПЗ (SRS), удосконалено складові компонент множини можливих джерел появи ризиків розроблення П3, а також розроблено формалізовану модель визначення можливих джерел появи потенційних ризиків відповідної множини зокрема та сумарних джерел появи потенційних ризиків загалом. 
1.2. Ідентифікація потенційних ризикових подій полягає у фіксації всіх чинників занепокоєння та стурбованості керівника проекту і зацікавлених сторін проекту, пов'язані з його безпосередньою реалізацією, а потім у постійному обдумуванні інших можливих побоювань. При цьому справжньою проблемою, тобто найбільшим занепокоєнням, $\epsilon$ такі ризикові події, які неможливо передбачити чи не вдалося ідентифікувати. На підставі провідних галузевих публікацій (Alferov, 2008; Braude, 2004; Fatrell, Shafer \& Shafer, 2003; Sommervill, 2002; Zyl, 2010) у роботі (Ostrovyj, Krasovskyj \& Grybynchuk, 2015) за зазначеними вище множинами компонент (1) вдалось ідентифікувати такі множини потенційних ризикових подій:

$$
\boldsymbol{R P}=\left\{\tilde{T}^{R}, \tilde{C}^{R}, \tilde{P}^{R}, \tilde{M}^{R}\right\} .
$$

$\mathrm{y}$ цьому виразі введено позначення таких компонент і їх складових:

- $\tilde{T}^{R}=\left\{t_{j}^{R}, j=\overline{1, n_{1}^{R}}\right\}, \tilde{T}^{R} \subset \boldsymbol{R P}$ - множина настання технічних ризикових подій, елементами якої $\epsilon: t_{1}^{R}, t_{2}^{R}$ - затримки у постачанні програмно-апаратних засобів, необхідних для підтримки процесу розроблення П3; $t_{3}^{R}, t_{4}^{R}$ - неефективне використання командою виконавців програмно-апаратних засобів розроблення ПЗ; $t_{5}^{R}$ - ухиляння команди виконавців від використання CASE-засобів розроблення ПЗ; $t_{6}^{R}$ - небажання керівника проекту придбати більш потужні програмно-апаратні засоби для розроблення ПЗ; $t_{7}^{R}-$ недостатня продуктивність баз(и) даних для підтримки процесу розроблення ПЗ; $t_{8}^{R}$ - присутні дефекти та обмежені функціональні можливості програмних компонент, які заплановано використовувати для розроблення ПЗ; $t_{9}^{R}-$ недосконалість програмного коду, згенерованого CASE-засобами розроблення ПЗ; $t_{10}^{R}$ - неможливість інтеграції CASE-засобів 3 іншими програмними засобами для підтримки процесу розроблення ПЗ; $t_{11}^{R}$ - мала швидкість виявлення дефектів у програмному коді від раніше запланованих термінів; $t_{12}^{R}-$ поява дефектів у програмних компонентах, розроблених підрядниками, які вже інтегровано в ПЗ, де $n_{1}^{R}=12$;

- $\tilde{C}^{R}=\left\{c_{j}^{R}, j=\overline{1, n_{2}^{R}}\right\}, \tilde{C}^{R} \subset \boldsymbol{R P}$ - множина настання вартісних ризикових подій, елементами якої $\epsilon: c_{1}^{R}, c_{2}^{R}-$ недо(пере)оцінювання витрат на етапи реалізації програмного проекту; $c_{3}^{R}$ - затримка фінансування виконання робіт у компанії-замовника ПЗ; $c_{4}^{R}-$ неналежне фінансування робіт, виконаних підрядником, у компанії-розробника ПЗ; $c_{5}^{R}-$ зменшення бюджету реалізації програмного проекту 3 ініціативи компанії-замовника П3; $c_{6}^{R}-$ збільшення бюджету реалізації програмного проекту з ініціативи компанії-розробника ПЗ; $c_{7}^{R}, c_{8}^{R}$ - значна вартість виконання повторних робіт, необхідних для зміни вимог до ПЗ, ініційованих як компанією-замовником, так і компанією-розробником; $c_{9}^{R}$ - реорганізація структурних підрозділів у компанії-замовника Пз; $c_{10}^{R}$ - часта зміна персоналу команди виконавців ПЗ, де $n_{2}^{R}=10$;

- $\tilde{P}^{R}=\left\{p_{j}^{R}, j=\overline{1, n_{3}^{R}}\right\}, \tilde{P}^{R} \subset \boldsymbol{R P}$ - множина настання планових ризикових подій, елементами якої $\epsilon: p_{1}^{R}, p_{2}^{R}-$ зміни графіка виконання робіт з боку компанії-замовника чи компанії-виконавця П3; $p_{3}^{R}-$ порушення графіка виконання робіт у компанії-розробника ПЗ; $p_{4}^{R}-$ потреба змі- ни користувацьких вимог до ПЗ з боку компанії його замовника; $p_{5}^{R}$ - потреба зміни системних вимог до ПЗ 3 боку компанії його розробника; $p_{6}^{R}-$ потреба виконання великої кількості повторних робіт, необхідних для зміни вимог до ПЗ; $p_{7}^{R}, p_{8}^{R}-$ недо(пере)оцінювання тривалості етапів реалізації програмного проекту з боку компаніїрозробника ПЗ; $p_{9}^{R}, p_{9}^{R}$ - остаточний розмір ПЗ значно більший/менший за планові його характеристики; $p_{11}^{R}$, $p_{12}^{R}$ - поява на ринку аналогічного/конкурентного ПЗ до виходу замовленого, де $n_{3}^{R}=12$;

- $\tilde{M}^{R}=\left\{m_{j}^{R}, j=\overline{1, n_{4}^{R}}\right\}, \tilde{M}^{R} \subset \boldsymbol{R P}-$ множина настання ризикових подій реалізації завдань управління програмним проектом, де: $m_{1}^{R}-$ низький моральний стан персоналу команди виконавців ПЗ; $m_{2}^{R}$ - неналежна взаємодія між персоналом команди виконавців ПЗ; $m_{3}^{R}, m_{4}^{R}$ - пасивність чи недостатня компетентність керівника проекту; $m_{5}^{R}-$ незадоволеність замовника результатами етапів реалізації програмного проекту; $m_{6}^{R}-$ недостатня кількість провідних фахівців у команді виконавців ПЗ; $m_{7}^{R}-$ хвороба провідного виконавця в найкритичніший момент розроблення ПЗ; $m_{8}^{R}$ - одночасна хвороба декількох виконавців ПЗ підчас реалізації програмного проекту; $m_{9}^{R}-$ неналежна організація необхідного навчання персоналу команди виконавців ПЗ; $m_{10}^{R}$ - зміна пріоритетів у процесі управління програмним проектом; $m_{11}^{R}, m_{12}^{R}$ - недо(пере)оцінювання необхідної кількості розробників (підрядників і субпідрядників) на етапах реалізації програмного проекту; $m_{13}^{R}, m_{14}^{R}$ - надмірне/недостатне документування продуктів проекту на етапах його реалізації; $m_{15}^{R}-$ нереальне прогнозування готовності продуктів проекту на етапах його реалізації; $m_{16}^{R}-$ недостатній професійний рівень представників від компанії-замовника $\Pi 3 ; m_{17}^{R}, m_{18}^{R}$ - низька кваліфікація бізнес- чи системних аналітиків програмного проекту, де $n_{4}^{R}=18$.

Аналіз провідних галузевих публікацій (Alferov, 2008; Braude, 2004; Fatrell, Shafer \& Shafer, 2003; Sommervill, 2002; Zyl, 2010) дав змогу ідентифікувати такі компоненти:

- технічних ризикових подій з ймовірністю їх ідентифікації $q_{1 j}^{R}=t_{j}^{R} \in[0 \ldots 1], j=\overline{1, n_{1}^{R}} ;$

- вартісних ризикових подій з ймовірністю їх ідентифікації $q_{2 j}^{R}=c_{j}^{R} \in[0 \ldots 1], j=\overline{1, n_{2}^{R}} ;$

- планових ризикових подій з ймовірністю їх ідентифікації $q_{3 j}^{R}=p_{j}^{R} \in[0 \ldots 1], j=\overline{1, n_{3}^{R}} ;$

- ризикових подій реалізації завдань управління програмним проектом 3 ймовірністю $q_{4 j}^{R}=m_{j}^{R} \in[0 \ldots 1], j=\overline{1, n_{4}^{R}}$.

3 урахуванням зазначеного вище сформуємо множину потенційних ризикових подій розроблення ПЗ, ймовірність ідентифікації яких матиме такий вигляд

$$
\tilde{\tilde{Q}}^{R}=\left\{\tilde{Q}_{i}^{R}=\left\{q_{i j}^{R} \in[0(0,01) 1], j=\overline{1, n_{i}^{R}}\right\}, i=\overline{1, M^{R}}\right\},
$$

де: $q_{i j}^{R}$ - ймовірність ідентифікації $j$-ої потенційної ризикової події з $i$-ої їх множини; $n_{i}^{R}-$ кількість потенційних ризикових подій розроблення ПЗ у $i$-ій множині; $M^{R}$ - кількість множин потенційних ризикових подій розроблення ПЗ. 
При цьому ймовірність ідентифікації потенційних ризикових події з $i$-ої їх множини визначаємо за такою формулою

$$
\tilde{Q}^{R}=\left\{q_{i}^{R}=\sum_{j=1}^{n_{i}^{R}} q_{i j}^{R}, i=\overline{1, M^{R}}\right\},
$$

а ймовірність ідентифікації сумарних ризикових подій - за такою формулою

$$
Q_{\Sigma}^{R}=\sum_{i=1}^{M^{R}} q_{i}^{R} .
$$

Тоді формалізована модель ідентифікації потенційних ризикових подій розроблення ПЗ відповідної множини має такий вигляд

$$
\tilde{G}^{R}=\left\{g_{i}^{R}=\frac{100}{N_{\Sigma}^{R}} q_{i}^{R}, i=\overline{1, M^{R}}\right\}, \%,
$$

а формалізована модель ідентифікації сумарних потенційних ризикових подій виглядатиме так

$$
G_{\Sigma}^{R}=\sum_{i=1}^{M^{R}} g_{i}^{R}, \%
$$

де: $g_{i}^{R}$ - ймовірність ідентифікації потенційних ризикових подій з $i$-ої їх множини; $N_{\Sigma}^{R}-$ повна ймовірність ідентифікації всіх потенційних ризикових подій розроблення ПЗ, визначаємо за такою формулою

$$
N_{\Sigma}^{R}=\sum_{i=1}^{M^{R}} n_{i}^{R} .
$$

На рис. 3 наведено результати ідентифікації потенційних ризикових подій розроблення ПЗ на підставі провідних галузевих публікацій.

Отже, згідно з результатами аналізу провідних галузевих публікацій, удосконалено компоненти множини потенційних ризикових подій розроблення ПЗ, а також розроблено формалізовану модель ідентифікації потенційних ризикових подій відповідної множини зокрема та сумарних потенційних ризикових подій загалом.

Eman 2. Аналіз ризиків розроблення ПЗ. Очевидно, що керівнику проекту боротися та впоратися з усіма ризиками його реалізації відразу дорого і малоефективно. Мета цього етапу полягає в тому, щоб проаналізувати ідентифіковані потенційні ризикові події розроблення П3, проранжувати їх за пріоритетами реагування на них, тобто потрібно виявити найбільш важливі з них. Для кожної ризикової події необхідно оцінити ймовірність їі настання та наслідки прояву (можливих збитків) за десятибальною шкалою. Перемноживши їх, отримаємо важливість ризику розроблення ПЗ. Позначимо також деяку межу важливості (наприклад, 50 і вище), щоб зрозуміти які ризики критичні й далі працювати тільки 3 ними.

Зазвичай, зібрані в інтерактивному режимі оцінки (ймовірності настання) потенційних ризикових подій від кожного з експертів зберігають у базі даних, доступ до якої здійснюють за допомогою відповідного програмного засобу. Отримання оцінок від експертів має проходити у вигляді їхнього опитування з використанням ранжованої шкали за кожною потенційною ризиковою подією розроблення ПЗ (Voronin, Ziatdinov \& Kulinskii, 2011). Кожен з експертів має виставити відповідні оцінки, які потім потрібно врахувати через відповідні коефіцієнти їх вагомості (рис. 4). Зрозуміло, кожна потенційна ризикова подія процесу розроблення ПЗ буде по різному впливати на іiі важливість, значення яких згодом маємо визначити для програмного проекту. Ок-

\begin{tabular}{|c|c|c|}
\hline Мнохина настання технічних ризиковихх подій & 6.56 & $16.00 \%$ \\
\hline затримки у постачанні обларнання, необхдного аля підтримки процесу розроблення ПЗ & 0.78 & \\
\hline затримки у постбчанні інструментальних засобів, необханих для підтримки процесу розроблення ПЗ & 0.58 & \\
\hline небажання команди виконавців використовувати інструментальні засоби для підтримки процесу розро & 0,64 & \\
\hline Формування запитів на більш потужні інструментальні засоби розроблення ПЗ & 0.78 & \\
\hline відмова команди виконавців від CASE-засобів розроблення ПЗ & 0.46 & \\
\hline неефективність програмного коду. згенерованого СASE-засобами розроблення ПЗ & 0.26 & \\
\hline неможливість інтеграші CASE-засобів з іншими інструментальними засобами аля підтримки процесу ре & 0.64 & \\
\hline недостатня продуктивність баз (и) даника аля підтримки процесу розроблення ПЗ & 0.22 & \\
\hline програмні компоненти, які використовують повторно в ПЗ, мають дефекти та обмежені Функцінальні ? & 0.24 & \\
\hline швидкість виявлення дефектів у програмному коді є нижчою від раніше запланованих термінів & 0.97 & \\
\hline поява дефекпиих системних компонент, які використовують для розроблення ПЗ & 0.99 & \\
\hline Мнохина настання вартісних ризикових подій & 3.06 & $7.46 \%$ \\
\hline недо(пере) оцінювання витрат на реалізашію програмного проекту (надмірно низька вартість) & 0.39 & \\
\hline Фінансові ускладнення у компаніі замовника ПЗ & 0.26 & \\
\hline фінансові ускладнення у компаниі розробника ПЗ & 0.69 & \\
\hline 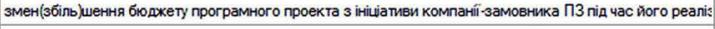 & $: 0.42$ & \\
\hline висока вартість виконання повторних робіт, необхірних аля зміни вимог до ПЗ & 0.24 & \\
\hline реорганізашія структурних підрозділів у компаніїзамововника ПЗ & 0.65 & \\
\hline реорганізашія команви виконавшів у компаниї розробника ПЗ & 0.41 & \\
\hline Мнохина настання планових ризиковихх подій & 4.42 & $10.78 \%$ \\
\hline эміни графіка виконання робіт з боку замовника чи розробника ПЗ & 0.12 & \\
\hline порушення графіка виконання робіт з боку компаніїрозробника П3 & 0.24 & \\
\hline потреба зміни користувашьких вимог до ПЗ з боку компанї-замовника ПЗ & 0.42 & \\
\hline потреба зміни Функціонапьних вимог до ПЗ з боку компанії розробиника ПЗ & 0.47 & \\
\hline порушення графіка виконання робіт з боку компаніі розробника П3 & 0.24 & \\
\hline потреба зміни користувацьких вимог до ПЗ з боку компаніі-замовника ПЗ & 0.42 & \\
\hline потреба зміни Функціональних вимог до ПЗ з боку компаніїрозробника ПЗ & 0.47 & \\
\hline потреба виконання великої кількості повторних робіт. необхонихх для зміни вимог до ПЗ & 0.97 & \\
\hline недо(пере)оцинювання тривалості етапів реалізаці програмного проекту з боку компаніі замовника П3 & 0.42 & \\
\hline остаточний розмір П3 значно перевищуе (менший вір) заплановані(их) його характеристики & 0.24 & \\
\hline поява на ринку аналогічного П3 до виходу замовленого & 0.61 & \\
\hline поява на ринку більш конкурентоздатного ПЗ & 0.93 & \\
\hline Мнохина настання ризикових подій реапізації процесу управління програмним проекте & 8.20 & $20.00 \%$ \\
\hline низький моральний стан персонапу команаи виконавшів ПЗ & 0.36 & \\
\hline низька взаеморія мік членами команди виконавців ПЗ & 0.41 & \\
\hline пасивність керівника (менеджера) програмного проекту & 0.88 & \\
\hline недостатня компетенттість керівника (менеджера) програмного проекпу & 0.69 & \\
\hline незадоволеність замовника результатами етапів реапізашї програмного проекту & 0.91 & \\
\hline 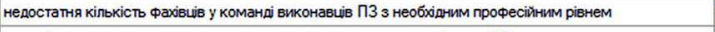 & 0.38 & \\
\hline хвороба провірного виконавця в найкритичніший момент розроблення ПЗ & 0.95 & \\
\hline одночасна хвороба декількох виконавшів підчас розроблення ПЗ & 0.74 & \\
\hline неможливість організаші необханого навчання персоналу команди виконавшів ПЗ & 0.36 & \\
\hline зміна пріоритетів у процесі управління програмним проектом & 0.26 & \\
\hline едо(пере)оцинювання необхрної кількості розробників (пірряяників і субпіррядників) на етапах розробле & $=0.78$ & \\
\hline едостапне (нармірне) документування результатів на етапах реалізаші програмного проекту & 0.23 & \\
\hline нереалістичне прогнозування результатів на етапах реалізаціі програмного проекту & 0.88 & \\
\hline недостаттій професійний рівень представників від компаніїзамовника ПЗ & 0.37 & $54,24 \%$ \\
\hline
\end{tabular}

рім цього, залежно від кваліфікації експерта кожний з них також матиме різні значення коефіцієнтів вагомості.

Етап 1.Ідентифікашія ризиків розроблення П3 Етап 2.Aнапіз ризиків розробпення П3 Ета丿 3. Планування ризиків розр Визначення можливих дхерел появи ризиків Lеентмфікашія потенниїних ризикових подй

Рис. 3. Форма для ідентифікації потенційних ризикових подій розроблення ПЗ

Введемо множину коефіцієнтів вагомості експертів для кожної з множини настання потенційних ризикових подій:

$$
\tilde{\tilde{W}}=\left\{\tilde{W}_{i}=\left\{w_{i, k}=[0(1) 10], k=\overline{1, K}\right\}, i=\overline{1, M^{R}}\right\},
$$

де: $w_{i, k}-$ коефіцієнт вагомості $k$-го експерта для $i$-ої множини настання потенційних ризикових подій; $0(1) 10$ - діапазон значень коефіцієнтів вагомостей експертів від 0 до 103 кроком $1 ; K$ - кількість експертів; $M^{R}$ - кількість множин потенційних ризикових подій розроблення ПЗ. Водночас, середнє значення коефіцієнтів вагомості для $i$-ої множини потенційних ризикових подій можна визначити за такою формулою

$$
\tilde{W}^{\mathrm{c}}=\left\{w_{i}^{\mathrm{c}}=\frac{1}{K} \sum_{k=1}^{K} w_{i, k}, i=\overline{1, M^{R}}\right\} .
$$

Початкові значення коефіцієнтів вагомості експертів, зазвичай, беруть емпірично, виходячи із їхньої важливості на початковому етапі розроблення ПЗ. Насправді ж ці значення потрібно визначати через відповідні тести за 100-бальною шкалою, результати яких і встановити реальні значення коефіцієнтів вагомості експер- 
тів (Hrytsiuk \& Zhabych, 2018). Для кожного окремого експерта, що бере участь в процедурі оцінювання потенційних ризикових подій, в базі даних має зберігатися сукупність виставлених ним оцінок (див. табл. 1). Також у цій базі даних мають зберігатися ознаки ролей кожного з експертів (Botsula \& Morhun, 2014; Paulk \&
Curtis, 2001) і коефіцієнти їхньої вагомості (рис. 4). Ці значення потрібно використати для врегулювання узагальнених показників настання потенційних ризикових подій, які стосуватимуться окремо статичних (професійних) і динамічних (потенційних користувачів) експертів.

Eтап 1.ІІдентифікашія ризиків розроблення П3 $\quad$ Етап 2.Аналіз ризиків розроблення П3 $\quad$ Eтап 3. Планування ризиків розроблення П3

Koефiшентп вагомості експертів Визначення ймовірності настання ризикових порій Визначення частки мохливих збитків від прояву ризику

Коефіцієнти вагомості кожного з експертів для множини настання ризикових подій

\begin{tabular}{|c|c|c|c|c|c|c|c|c|c|c|c|}
\hline & Eксперт\#1 & Eксперт̈2 & Експерт\#3 & Eксперт\#4 & Eксперт\#5 & Eкcперт\#6 & Eкcперт\#7 & Eксперт\#8 & Eксперт\#9 & Eкcnерт\#10 & Середне \\
\hline Мнохина настання тежн-інних ризикових подій & 10 & 9 & 10 & 10 & 7 & 8 & 10 & 9 & 9 & 10 & 9.20 \\
\hline Мнохина настання вартісних ризикових подій & 7 & 8 & 8 & 8 & 10 & 9 & 8 & 10 & 8 & 8 & 8.40 \\
\hline Мнохина настання планових ризикових порій & 9 & 9 & 10 & 9 & 9 & 10 & 10 & 7 & 10 & 10 & 9.30 \\
\hline Мнохина настання ризикових порій реалізаціі процесу & 8 & 9 & 7 & 10 & 8 & 9 & 8 & 10 & 8 & 10 & 8.70 \\
\hline
\end{tabular}

Коефіцієнти вагомості кожного з експертів для можливих збитків від настання ризикових подій

\begin{tabular}{|c|c|c|c|c|c|c|c|c|c|c|c|}
\hline & Eксперт\#1 & Eкcnept\#2 & Експерт\#3 & Eксперт\#4 & Eксперт\#5 & Eксперт\#6 & Eксперт\#7 & Eкcnepт\#8 & Eкcnepт\#9 & Eксnерт\#10 & Середнє \\
\hline Множина настання технічних ризикових порій & 7 & 8 & 9 & 10 & 10 & 9 & 7 & 8 & 9 & 8 & 8.50 \\
\hline Мнохина настання вартісних ризикових подій & 9 & 7 & 8 & 6 & 6 & 9 & 7 & 8 & 8 & 5 & 7.30 \\
\hline Мнохина настання планових ризикових подій & 5 & 9 & 8 & 9 & 6 & 10 & 6 & 8 & 7 & 6 & 7.40 \\
\hline Множина настання ризикових подій реалізаці́і про & 9 & 10 & 9 & 7 & 10 & 7 & 9 & 9 & 9 & 9 & 8.80 \\
\hline
\end{tabular}

Рис. 4. Коефіцієнти вагомості експертів

\section{1. Визначення ймовірності настання потенційних} ризикових подій. Для кожного ризику з множини потенційних ризикових подій (6) кожен 3 експертів має встановити ймовірність його настання в діапазоні [0...1] 3 кроком 0,01. Для цього варто побудувати табл. 1, в яку потрібно занести значення цих ймовірностей.

Табл. 1. Встановлені експертами ймовірності настання потенційних ризикових подій

\begin{tabular}{|c|c|c|c|c|c|c|c|c|}
\hline \multirow{2}{*}{$\begin{array}{c}\text { № } \\
3 / \Pi\end{array}$} & $\begin{array}{c}\text { Ризи- } \\
\text { кові } \\
\text { подіï }\end{array}$ & \multicolumn{2}{|c|}{ Оцінки експертів у діапазоні $[0 \ldots 1]$} & \multicolumn{2}{|c|}{ Сумарні } \\
\hline & & $w_{1,1}$ & $w_{1,2}$ & $\ldots$ & $w_{1, K-1}$ & $w_{1, K}$ & $w_{1}^{\mathrm{c}}$ & $g_{1}^{R}$ \\
\hline 1 & $t_{1}^{R}$ & $d_{1,1,1}^{P}$ & $d_{1,1,2}^{P}$ & $\ldots$ & $d_{1,1, K-1}^{P}$ & $d_{1,1, K}^{P}$ & $g_{1,1}^{R}$ & \\
\hline$\ldots$ & $\ldots$ & $\ldots$ & $\ldots$ & $\ldots$ & $\ldots$ & $\ldots$ & $\ldots$ & \\
\hline$n_{1}^{R}$ & $t_{11}^{R}$ & $d_{1, n_{1}^{R}, 1}^{P}$ & $d_{1, n_{1}^{R}, 2}^{P}$ & $\ldots$ & $d_{1, n_{1}^{R}, K-1}^{P}$ & $d_{1, n_{1}^{R}, K}^{P}$ & $g_{1, n_{1}^{R}}^{R}$ & \\
\hline & & $w_{2,1}$ & $w_{2,2}$ & $\ldots$ & $w_{2, K-1}$ & $w_{2, K}$ & $w_{2}^{\mathrm{c}}$ & $g_{2}^{R}$ \\
\hline 1 & $c_{1}^{R}$ & $d_{2,1,1}^{P}$ & $d_{2,1,2}^{P}$ & $\ldots$ & $d_{2,1, K-1}^{P}$ & $d_{2,1, K}^{P}$ & $g_{2,1}^{R}$ & \\
\hline$\ldots$ & $\ldots$ & $\ldots$ & $\ldots$ & $\ldots$ & $\ldots$ & $\ldots$ & $\ldots$ & \\
\hline$n_{2}^{R}$ & $c_{8}^{R}$ & $d_{2, n_{2}^{R}, 1}^{P}$ & $d_{2, n_{2}^{R}, 2}^{P}$ & $\ldots$ & $d_{2, n_{2}^{R}, K-1}^{P}$ & $d_{2, n_{2}^{R}, K}^{P}$ & $g_{2, n_{2}^{R}}^{R}$ & \\
\hline & & $w_{3,1}$ & $w_{3,2}$ & $\ldots$ & $w_{3, K-1}$ & $w_{3, K}$ & $w_{2}^{\mathrm{c}}$ & $g_{2}^{R}$ \\
\hline 1 & $p_{1}^{R}$ & $d_{3,1,1}^{P}$ & $d_{3,1,2}^{P}$ & $\ldots$ & $d_{3,1, K-1}^{P}$ & $d_{3,1, K}^{P}$ & $g_{3,1}^{R}$ & \\
\hline$\ldots$ & $\ldots$ & $\ldots$ & $\ldots$ & $\ldots$ & $\ldots$ & $\ldots$ & $\ldots$ & \\
\hline$n_{3}^{R}$ & $p_{11}^{R}$ & $d_{3, n_{3}^{R}, 1}^{P}$ & $d_{3, n_{3}^{R}, 2}^{P}$ & $\ldots$ & $d_{3, n_{3}^{R}, K-1}^{P}$ & $d_{3, n_{3}^{R}, K}^{P}$ & $g_{3, n_{3}^{R}}^{R}$ & \\
\hline & & $w_{4,1}$ & $w_{4,2}$ & $\ldots$ & $w_{4, K-1}$ & $w_{4, K}$ & $w_{4}^{\mathrm{c}}$ & $g_{2}^{R}$ \\
\hline 1 & $m_{1}^{R}$ & $d_{4,1,1}^{P}$ & $d_{4,1,2}^{P}$ & $\ldots$ & $d_{4,1, K-1}^{P}$ & $d_{4,1, K}^{P}$ & $g_{4,1}^{R}$ & \\
\hline$\ldots$ & $\ldots$ & $\ldots$ & $\ldots$ & $\ldots$ & $\ldots$ & $\ldots$ & $\ldots$ & \\
\hline$n_{4}^{R}$ & $m_{16}^{R}$ & $d_{4, n_{4}^{R}, 1}^{P}$ & $d_{4, n_{4}^{R}, 2}^{P}$ & $\ldots$ & $d_{4, n_{4}^{R}, K-1}^{P}$ & $d_{4, n_{4}^{R}, K}^{P}$ & $g_{4, n_{4}^{R}}^{R}$ & $G_{\Sigma}^{R}$ \\
\hline
\end{tabular}

Отже, множина ймовірностей настання потенційних ризикових подій розроблення ПЗ, яку виставляє кожний експерт, матиме такий вигляд:

$$
\tilde{\tilde{\tilde{D}}}^{P}=\left\{\tilde{\tilde{D}}_{i}^{P}=\left\{\tilde{D}_{i j}^{P}=\left\{d_{i j k}^{P}, k=\overline{1, K}\right\}, j=\overline{1, n_{i}^{R}}\right\}, i=\overline{1, M^{R}}\right\},
$$

де: $d_{i j k}^{P} \in[0(0,01) 1]-$ ймовірність настання $j$-ої ризикової події для $i$-ої їх множини, яку виставив $k$-ий експерт; $K$ - кількість потенційних експертів.

Тоді формалізована модель визначення усередненого (середньозваженого) значення ймовірності настання потениійної ризикової події розроблення ПЗ відповідної множини з урахуванням кваліфікації відповідних експертів (15) має такий вигляд

$$
\tilde{\tilde{G}}^{P}=\left\{\tilde{G}_{i}^{P}=\left\{g_{i j}^{P}=\frac{K}{w_{i}^{\mathrm{c}}} \sum_{k=1}^{K} d_{i j k}^{P} \cdot w_{i k}, j=\overline{1, n_{i}^{R}}\right\}, i=\overline{1, M^{R}}\right\}, \%,
$$

а формалізована модель визначення усереднених значень ймовірностей настання потенційних ризикових подій розроблення ПЗ для кожної множини виглядатиме так

$$
\tilde{G}^{P}=\left\{g_{i}^{P}=\frac{1}{n_{i}^{R}} \sum_{j=1}^{n_{i}^{R}} g_{i j}^{P}, i=\overline{1, M^{R}}\right\}, \%,
$$

водночас як формалізована модель визначення сумарної ймовірності настання потенційних ризикових подій розроблення ПЗ виглядатиме так

$$
G_{\Sigma}^{P}=\sum_{i=1}^{M^{R}} g_{i}^{P}, \%
$$

де: $g_{i j}^{P}-$ усереднене значення ймовірності настання $j$-ої ризикової події для $i$-ої їх множини; $g_{i}^{P}-$ усереднене значення ймовірностей настання ризикових подій для $i$ ої множини.

Згідно з результатами аналізу провідних галузевих публікацій (Alferov, 2008; Braude, 2004; Fatrell, Shafer \& Shafer, 2003; Sommervill, 2002; Zyl, 2010), сформуємо правила класифікації потенційних ризикових подій за іхніми ймовірностями настання:

1) якщо $g_{i j}^{P}<10$, то ймовірність настання ризикової події $g_{i j}^{P} \in$ дуже низькою;

2) якщо $\left(g_{i j}^{P} \geq 10\right) \wedge\left(g_{i j}^{P}<25\right)$, то ймовірність настання ризикової події $g_{i j}^{P} \in$ низькою;

3) якщо $\left(g_{i j}^{P} \geq 25\right) \wedge\left(g_{i j}^{P}<50\right)$, то ймовірність настання ризикової події $g_{i j}^{P} \in$ середньою;

4) якщо $\left(g_{i j}^{P} \geq 50\right) \wedge\left(g_{i j}^{P}<75\right)$, то ймовірність настання ризикової події $g_{i j}^{P}$ є високою;

5) якщо $g_{i j}^{P} \geq 75$, то ймовірність настання ризикової події $g_{i j}^{P} є$ дуже високою,

де $\tilde{G}_{i}^{P}=\bigcup_{j=1}^{n_{i}^{R}} g_{i j}^{P}, i=\overline{1, M^{R}}$.

На рис. 5 наведено результати визначення ймовірностей настання потенційних ризикових подій розроблення ПЗ на підставі провідних галузевих публікацій. 
Отже, згідно з результатами аналізу провідних галузевих публікацій розроблено формалізовану модель визначення усередненого значення ймовірності настання потенційної ризикової події розроблення ПЗ відповідної множини з урахуванням кваліфікації відповідних експертів і для кожної множини зокрема, а також для сумарної ймовірності настання потенційних ризикових подій загалом. Також сформовано правила класифікації потенційних ризикових подій за їхніми ймовірностями настання.

\begin{tabular}{|c|c|c|c|c|c|c|c|c|c|c|c|c|c|c|c|c|c|c|c|c|c|c|c|c|}
\hline \multirow{2}{*}{\multicolumn{2}{|c|}{ 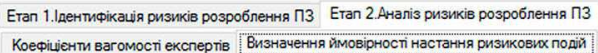 }} & \multicolumn{23}{|c|}{ Етап 3. Планування ризиків розроблення ПЗ } \\
\hline & & \multicolumn{23}{|c|}{ Визначення частки мохливих збитків від прояву ризику } \\
\hline \multirow{2}{*}{\multicolumn{2}{|c|}{ Визначення ймовірності настання ризикових подій }} & \multicolumn{11}{|c|}{ Oürkи експертів у даaпазоні [0...1] } & \multicolumn{12}{|c|}{ Оuнкки експертів з урахуванням їхььої ваго } \\
\hline & & 1 & 2 & & $\frac{4}{\text { कivertm }}$ & A sarome & $\frac{6}{\text { nостікож }}$ & $\frac{7}{1 \text { xного } 3}$ & $\frac{8}{3 \text { експе }}$ & & & & 1 & 2 & 3 & 4 & 5 & 6 & 7 & 8 & 9 & 10 & & $\begin{array}{l}\text { Йммвірність } \\
\text { виникнення }\end{array}$ \\
\hline Мнохина настання технічних ризикових подій & 6.56 & 10 & 9 & 10 & 10 & & 8 & 10 & 9 & 9 & 10 & 92 & 5.5 & 4.57 & 4.88 & 4.75 & 3.59 & 4.40 & 4.27 & 1.82 & 3.83 & 2.67 & 44.37 & середньото \\
\hline затримки у постачанні облаянання. необхрного аля піртримки процесу ро. & 0.78 & 0.80 & 0.72 & 0.48 & 0.70 & 0.29 & 0.54 & 0.41 & 0.24 & 0.33 & 0.26 & 0.48 & 8.00 & 6.48 & 4.80 & 7.00 & 2.03 & \begin{tabular}{|l|l}
4.32 & 4 \\
4
\end{tabular} & 4.10 & 2.16 & 2.97 & 2.60 & 48.35 & cepentiboro \\
\hline затримки у постачанні інструментальних засобів, необхданих аля підтримк. & 0.58 & 0.78 & 0.48 & .41 & 0.45 & 0.31 & 0.66 & 0.350 & 0.21 & 0.51 & 0.28 & 0.44 & 7.80 & 4.32 & 4.10 & 4.50 & 2.17 & 5.28 & 3.50 & 1.89 & 4.59 & 2.80 & 15.21 & cepentiboro \\
\hline небажання команди виконавців використовувати інструментальні засоби ... & 0,64 & 0.44 & 0.25 & 0.69 & 0.49 & 0.45 & 0.40 & 0.630 & 0.20 & 0.45 & 0.28 & 0.43 & 4,40 & 2.25 & 6.90 & 4.90 & 3.15 & 3.20 & 6,30 & 1.80 & 4.05 & 2,80 & 43.42 & ереднььон \\
\hline Формування запитів на більш потужні інструментальні зассоби розробленн... & 0.78 & 0.70 & 0.73 & 0.54 & 0.28 & 0.73 & 0.76 & 0.54 & 0.19 & 0.30 & 0.25 & 0.50 & 7.00 & 6.57 & 5.40 & 2.80 & 5.11 & 6.08 & 5.40 & 1.71 & 2.70 & 2.50 & 49.37 & epentbowo \\
\hline відмова ко & 0.46 & 0.64 & 0.68 & 0.30 & 0.15 & 0.20 & 0.78 & 0.16 & 0.14 & 0.44 & 0.24 & 0.37 & 6.40 & 6.12 & 3.00 & 1.50 & 1.40 & 6.24 & 1.60 & 1.26 & 3.96 & 2.40 & 37.36 & cepention \\
\hline неефективність & 0.26 & 0.68 & 0.39 & 0.86 & 0.53 & 0.60 & 0.56 & 0.51 & 0.29 & 0.72 & 0.32 & 0.55 & 6.80 & 3.51 & 8.60 & 5.30 & 4.20 & 4.48 & 5.10 & 2.61 & 6.48 & 3.20 & 55.27 & високою \\
\hline тапьними засоб... & 0.64 & 0.72 & 0.27 & 0.22 & 0.70 & 0.69 & 0.71 & 0.40 & 0.20 & 0.50 & 0.27 & 0.47 & 7.20 & 2.43 & 2.20 & 7.00 & 4.83 & 5.68 & 4.00 & 1.80 & 4.50 & 2.70 & 6.23 & ереднысон \\
\hline недост & 0.22 & 0.18 & 0.60 & 0.16 & 0.51 & 0.29 & 0.50 & 0.49 & 0.21 & 0.46 & 0.16 & 0.36 & 1.80 & 5.40 & 1,60 & 5.10 & 2.03 & 4,00 & 4.90 & 1.89 & 4.14 & 1.60 & 5.22 & pequtboro \\
\hline програ & 0.24 & 0.29 & 75 & 0. & 0.70 & 0.51 & 0.80 & 0.25 & 0.21 & 0.20 & 0.32 & 0.47 & 2.90 & 6.75 & 70 & 7.00 & 3.57 & 6.40 & 2.50 & 1.89 & 1.80 & 3.20 & 46.31 & epentiboro \\
\hline еза... & 0.97 & 0.33 & 0.21 & 0.71 & 0.55 & 0.88 & 0.18 & 0.83 & 0.19 & 0.21 & 0.28 & 0.44 & 3.30 & 1.89 & 7.10 & 5.50 & 6.16 & 1.44 & 8.30 & 1.71 & 1.89 & 2.80 & 44.42 & \\
\hline поява дес & 0.99 & 0.49 & 0.50 & 0.33 & 0.17 & 0.69 & 0.16 & 0.13 & 0.15 & 0.56 & 0.28 & 0.35 & 4.90 & 4.50 & 3.30 & 1.70 & 4.83 & 1.28 & 1.30 & 1.35 & 5.04 & 2.80 & 34.27 & ереднtboro \\
\hline Мнохина настання вартісних ризикових подій & 3,06 & 7 & 8 & 8 & 8 & 10 & 9 & 8 & 10 & & 8 & 84 & 2.17 & 4.96 & 2.51 & 1.86 & 2.10 & 3.19 & 1.52 & 2,96 & 2.94 & 1,66 & 31.47 & середнысок \\
\hline недо(пере)оинювання витг & 0.39 & 0.36 & 0.85 & 0.31 & 0.32 & 0.17 & 0.56 & 0.21 & 0.51 & 0.18 & 0.35 & 0.38 & 2.52 & 6.80 & 2.48 & 2.56 & 1.705 & \begin{tabular}{|l|l}
5.04 & 1 \\
\end{tabular} & 1.68 & 5.10 & 1.44 & 2.80 & 38.32 & ерепньою \\
\hline фінансо & 0.26 & 0.46 & 0.67 & 0.30 & 0.13 & 0.19 & 0.12 & 0.20 & 0.22 & 0.30 & 0.11 & 0.27 & 3.22 & 5.36 & 2.40 & 1.04 & 1.90 & 1.08 & 1.60 & 2.20 & 2.40 & 0.88 & 6.43 & ереднььо \\
\hline Фimar & 0.69 & 0.38 & 56 & 0. & 0.21 & 0.11 & 0.54 & 0.11 & 0.15 & 0.26 & 0.12 & 0.26 & 2.66 & 4.48 & 1.68 & 1.68 & 1.10 & & 88 & 50 & 2.08 & 0.96 & 6.27 & mo \\
\hline змент ( & 0.4 & 0.39 & 45 & 0. & 0.38 & 0.27 & 0.40 & 0.220 & 0.25 & 0.50 & 0.24 & 0.34 & 2.73 & 3.60 & 2.48 & 3.04 & 70 & & 76 & 50 & 4.00 & 1.92 & 1.31 & ono \\
\hline Bисока & 0.2 & 0.16 & 34 & & 0.2 & 0.2 & 0.3 & 0.2 & 0.13 & 0.35 & 0.15 & 0.24 & 1.12 & 2.72 & 64 & 1.84 & 2. & 2 & 76 & 30 & 2.80 & 1.20 & 1.43 & \\
\hline & 0.6 & 0.19 & & & & & & & 0.46 & 0.51 & 0.33 & 0.34 & 1.33 & 68 & 2,64 & 1.52 & 2. & 1. & 1.52 & 60 & 4.08 & 2,64 & & \\
\hline peopram & 0.41 & 0.23 & 0.76 & 0.41 & 0.17 & 0.27 & 0.33 & 0.180 & 0.35 & 0.47 & 0.15 & 0.33 & 1.61 & 6.08 & 3,28 & 1.36 & 2,70 & 2.97 & 1.44 & 3.50 & 3.76 & 1.20 & 3.47 & ow \\
\hline Мнохин & 4.42 & 9 & 9 & 10 & 9 & 9 & 10 & 10 & 7 & 10 & 10 & 93 & 4.12 & 5.28 & 5.81 & 3.23 & 2.98 & 3.485 & 5.20 & 1.63 & 5.97 & 3.82 & 45.28 & cеpen \\
\hline зміни графіка виконання р & 0.12 & 0.67 & 0.70 & 0.84 & 0.46 & 0.34 & 0.37 & 0.73 & 0.22 & 0.77 & 0.53 & 0.56 & 6.03 & 6.30 & 8.40 & 4.14 & \begin{tabular}{|l|l}
3.06 & 3 \\
\end{tabular} & 3.707 & 7.30 & 1.54 & 7.70 & 5.30 & .44 & \\
\hline поруше & 0.24 & 0.58 & 35 & 0. & 0.38 & 0,33 & 27 & 0.31 & 0.26 & 0.51 & 0,34 & 0.41 & 5.22 & 3.15 & 8.10 & 3.42 & 97 & 2. & 3.10 & 1.82 & 5,10 & 3,40 & 2.38 & ерертьо口о \\
\hline & 0.42 & 0.18 & & & 0.30 & & & & & 0.49 & 0.18 & 0.35 & 62 & 75 & 60 & 2.70 & 34 & & 4,40 & 1.61 & 4.90 & 1.80 & .26 & boto \\
\hline обника ПЗ & 0.47 & 0.75 & & & 0.5 & & 0.57 & 0.53 & 27 & 0.80 & 0.74 & 0.60 & 6.75 & 6.75 & 7.60 & 4.50 & 3. & 5. & 30 & 1.89 & 8.00 & 7.40 & 2.39 & \\
\hline notpe & 0.97 & 0.56 & & & & & & & & 0.72 & 0.52 & 0.45 & 5.04 & 2.07 & 6.80 & 2.61 & 3. & 3. & 30 & 1.68 & 7.20 & 5.20 & 33 & HbONO \\
\hline MHoro проекту з... & 0.42 & 0.58 & 53 & & 45 & 0. & 34 & 940 & 28 & 0,84 & 0.33 & 0.50 & 5.22 & 4.77 & 5.30 & 4.05 & 1.89 & 3.40 & 40 & 1.96 & 8.40 & 3.30 & 1.27 & кoro \\
\hline остат & 0.24 & 0.42 & & 57 & 0.25 & 0.20 & 0.37 & 0.19 & 0.21 & 0.67 & 0.22 & 0.37 & 3.78 & 5.13 & 5.70 & 2.25 & 1.80 & 3.70 & 1.90 & 1.47 & 6.70 & 2,20 & 71 & \\
\hline поява । & 0.61 & 017 & 60 & 0.21 & .24 & 0.43 & 0.18 & 0.49 & 0.15 & 0.24 & 0.27 & 0.30 & 1.53 & 5.40 & 2,10 & 2.16 & 3.87 & 1.80 & 4.90 & 1.05 & 2.40 & 270 & 39 & \\
\hline появан ң & 0.93 & 0.21 & 80 & 57 & .36 & 0.42 & 0.30 & 0.52 & 0.23 & 0.33 & 0.31 & 0.40 & 1.89 & 7.20 & 5.70 & 3.24 & 3.78 & 3.00 & 5.20 & 1.61 & 3.30 & 3.10 & 13 & \\
\hline & 8.20 & 8 & 9 & 7 & 10 & 8 & 9 & 8 & 10 & 8 & 10 & 87 & 3.34 & 2.84 & 2.26 & 3.51 & 1.81 & 2.46 & & & 3. & 4.19 & 5.32 & \\
\hline & & & & & & 0. & & 0.48 & 0.30 & 0.16 & 0.41 & 0.31 & 88 & 1.44 & 3.08 & 4.40 & 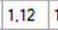 & & & 3.00 & 1.28 & 4.10 & & \\
\hline & & & & & & & & & & 0.16 & 0.39 & 0.29 & 92 & 1.80 & 1.89 & 4.70 & & & & & 1.28 & 3.90 & & \\
\hline & & & & & & 2 & & & & 0.73 & 0.49 & 0.44 & 12 & 3.15 & 2.52 & 2.70 & & & & 2.90 & 5.84 & 4.90 & & \\
\hline & & 0.27 & & & & 0.20 & & 330 & 51 & 0.68 & 0.29 & 0.33 & 2.16 & 0.99 & 3.01 & 2.00 & & & & 10 & 5.44 & 2.90 & & \\
\hline рамного ... & 0.91 & 0.46 & & & 50 & 0.29 & 0.21 & 0.190 & 0.41 & 0.44 & 0.41 & 0.37 & 3,68 & 3.87 & 2,66 & 5.00 & 2,32 & .89 & 1.52 & 4.10 & 3.52 & 4.10 & 8.42 & \\
\hline Сть Фахввців у команді виконавців ПЗ з необхонним проф... & 0.38 & 25 & 66 & 28 & 25 & 0,23 & 0.40 & 0.210 & 0.48 & 0.19 & 0,68 & 0.36 & 2.00 & 5.94 & 1.96 & 2.50 & 1.843 & 3.60 & 1.68 & 4.80 & 1.52 & 6.80 & 8.17 & редня \\
\hline онавця в найкритичніший момент розроблення П3 & 0.95 & 0.37 & 50 & 0.21 & 0.22 & 0.19 & 0.36 & 0.680 & 0.29 & 0.35 & 0.37 & 0.35 & 2.96 & 4.50 & 1.47 & 2.20 & 1.52 & 3.24 & 5.44 & 2.90 & 2.80 & 3.70 & 5.30 & ередня \\
\hline Одночас & 0.74 & 0.51 & 0.17 & 0.43 & 0.27 & 0.20 & 0.26 & 0.20 & 0.20 & 0.39 & 0.66 & 0.33 & 4.08 & 1.53 & 3.01 & 2.70 & 1.60 & 2.34 & 1.60 & 2.003 & 3.12 & 6.60 & 3.42 & ередня \\
\hline немож & 0.36 & 0.41 & 0.67 & 0.36 & 0.34 & 0.29 & 0.16 & 0.26 & 0.22 & 0.37 & 0.16 & 0.32 & 3.28 & 6.03 & 2,52 & 3.40 & 2,32 & 1.44 & 2.08 & 2.20 & 2.96 & 1.60 & 2.35 & редня \\
\hline & 0.2 & 0.46 & 39 & 22 & 23 & 0.25 & 32 & 10 & 0.12 & 0.35 & 0.26 & 0.30 & 3.68 & 3.51 & 2,24 & 2.30 & 2.00 & 88 & 2.48 & 1.20 & 2,80 & 2.60 & 30.07 & \\
\hline & 0.7 & 0.54 & & & 55 & 29 & 32 & 0.62 & 0.17 & 0.28 & 0.32 & 0.36 & 32 & 1.89 & 1.89 & 5.50 & 2.32 & 2.88 & 4.96 & 1.70 & 2.24 & 3.20 & 42 & \\
\hline & & & & & 55 & & & & & & & 34 & & 1.71 & 1.89 & 5.50 & 60 & & & 90 & 32 & 30 & & \\
\hline & & & & & & & & & & & & & & .98 & 45 & 00 & & & & & & 80 & & \\
\hline & & & & & & & & & & & & & 1.84 & 1.44 & 1.05 & 3.30 & 1.84 & & & & & 5.20 & 32.07 & \\
\hline
\end{tabular}

Рис. 5. Форма для визначення ймовірності настання ризикових подій розроблення ПЗ

\section{2. Розподіл вартості реалізації програмного про-} екту між множинами потениійних ризикових подій. Процес реалізації програмного проекту варто розглядати як основу діяльності його керівника: 3 ним пов'язано і цілі проекту - остаточні й проміжні, розподіл і контроль за витратами ресурсів, у т.ч. й фінансових, а також усі інші особливості управління ризиками реалізації проекту. Передусім цю прив'язку обумовлено поділом процесу розроблення ПЗ на етапи, які асоціюються 3 певними видами виконання робіт або функціями, які мають виконувати його розробники у той чи інший момент реалізації програмного проекту. Ці етапи характеризуються спрямованістю виконуваних функцій на досягнення локальних (для етапу) цілей проекту з урахуванням різних потенційних ризикових подій. У нашому випадку ці ризикові події поділено за декількома множинами їх настання, що і використаємо для розподілу вартості реалізації програмного проекту. Як уже було зазначено на початку Етапу 2, для кожної ризикової по- дії потрібно оцінити ймовірність іï настання (див. п. 2.1) та наслідки прояву - можливих збитків. Перемноживши їх, отримаємо важливість ризику розроблення П3, який треба враховувати в програмному проекті.

Зазвичай, в технічному завданні на підготовку програмного проекту вказують орієнтовну вартість його реалізації. Нехай $V_{Z}^{R}$ - початкова загальна вартість реалізації програмного проекту (тис. грн). Оскільки відома кількість множин потенційних ризикових подій розроблення ПЗ, то, з урахуванням (8), початкову вартість реалізації проекту варто пропорційно розподілити між цими множинами за такою формулою

$$
\tilde{V}^{R}=\left\{v_{i}^{R}=\frac{V_{Z}^{R} \cdot q_{i}^{R}}{100}, i=\overline{1, M^{R}}\right\}, \text { тис. грн, }
$$

де: $v_{i}^{R}$ - початкова вартість ідентифікації потенційних ризикових подій з $i$-ої їх множини. 3 врахуванням (9) сформуємо множину початкових вартостей ідентифікації потенційних ризикових подій розроблення ПЗ, яка матиме такий вигляд 


$$
\tilde{\tilde{V}}^{R}=\left\{\tilde{V}_{i}^{R}=\left\{v_{i j}^{R}=v_{i}^{R} \cdot \frac{q_{i j}^{R}}{Q_{\Sigma}^{R}}, j=\overline{1, n_{i}^{R}}\right\}, i=\overline{1, M^{R}}\right\} \text {, тис. грн, }
$$

де: $v_{i j}^{R}$ - початкова вартість ідентифікації j-ої потенційної ризикової події з $i$-ої їх множини. На рис. 5 наведено розподіл вартості реалізації програмного проекту за множинами потенційних ризикових подій.

2.3. Визначення частки та величини можливих збитків від настання потенційних ризикових подій (математичне сподівання збитку), тобто на скільки постраждає програмний проект, якщо ризикова подія все ж таки відбудеться.

Для визначення частки можливих збитків від настання потенційних ризикових подій можна використати два підходи. Перший 3 них полягає в тому, що для кожного ризику 3 множини потенційних ризикових подій (6) кожен 3 експертів мав би встановити ймовірність потенційного збитку від настання таких подій в діапазоні [0...1] з кроком 0,01. Для цього також варто побудувати табл. 2, аналогічну табл. 1, в яку потрібно занести значення цих ймовірностей. Однак, якщо кожен з експертів для кожного ризику з множини потенційних ризикових подій (6) ще може встановити ймовірність його настання, то встановити частку можливих збитків від настання потенційних ризикових подій - занадто важке і не вдячне завдання.

Тому скористаємось другим підходом, згідно з яким вважатимемо, що встановлені експертами в табл. 1 ймовірності настання потенційних ризикових подій безпосередньо стосуються можливих збитків від їх настання за такої умови. Справа в тому, що чим вища ймовірність настання потенційних ризикових подій, тим легше ці події передбачити, завчасно до них підготуватися i, як наслідок, отримати менші можливі збитки від їх настання. Наприклад, при 100 \% прогнозуванні ризикової події збитки від неї будуть практично нульовими. Тому частку можливих збитків від настання потенційних ризикових подій, яку мав би виставити кожний експерт, з урахуванням (16) можна визначити за такою формулою:

$$
\tilde{\tilde{\tilde{D}}}^{Z}=\left\{\tilde{\tilde{D}}_{i}^{Z}=\left\{\tilde{D}_{i j}^{Z}=\left\{d_{i j k}^{Z}=1-d_{i j k}^{P}, k=\overline{1, K}\right\}, j=\overline{1, n_{i}^{R}}\right\}, i=\overline{1, M^{R}}\right\},
$$

де: $d_{i j k}^{z}$ - частка можливого збитку від настання $j$-ої ризикової події для $i$-ої їх множини, яку мав би виставити $k$-ий експерт.

Тоді формалізована модель визначення усередненого (середньозваженого) значення величини можливого збитку від настання потенційних ризикових подій розроблення ПЗ відповідної множини з урахуванням кваліфікації відповідних експертів (15) має такий вигляд

$$
\tilde{\tilde{V}}^{D}=\left\{\tilde{V}_{i}^{D}=\left\{v_{i j}^{D}=\frac{K \cdot v_{i j}^{R}}{w_{i}^{\mathrm{c}}} \sum_{k=1}^{K} d_{i j k}^{Z} \cdot w_{i k}, j=\overline{1, n_{i}^{R}}\right\}, i=\overline{1, M^{R}}\right\},
$$

де: $v_{i j}^{D}$ - усереднена величина можливого збитку від настання $j$-ої ризикової події для $i$-ої їх множини, тис. грн. Варто зазначити, що це так зване математичне сподівання збитку є не що інше, як левова частка додаткової вартості розроблення ПЗ через можливі наслідки від настання потенційних ризикових подій, яку проектанти мають вносити в кошторис загальних витрат, а також ці витрати необхідно покрити замовником ПЗ для успішної реалізації програмного проекту.
Отже, формалізована модель визначення остаточної вартості розроблення ПЗ з урахуванням наслідків від настання потенційної ризикової подї відповідної множини має такий вигляд

$$
\tilde{\tilde{V}}^{O}=\left\{\tilde{V}_{i}^{O}=\left\{v_{i j}^{O}=v_{i j}^{R}+v_{i j}^{D}, j=\overline{1, n_{i}^{R}}\right\}, i=\overline{1, M^{R}}\right\} \text {, тис. грн, (24) }
$$

а формалізована модель визначення остаточної вартості розроблення ПЗ з урахуванням наслідків від настання потениіийнх ризикових подій для кожної множини виглядатиме так

$$
\tilde{V}^{O}=\left\{v_{i}^{O}=\sum_{j=1}^{n_{i}^{R}} v_{i j}^{O}, i=\overline{1, M^{R}}\right\}, \text { тис. грн, }
$$

водночас як формалізована модель визначення сумарної остаточної вартості розроблення ПЗ з урахуванням наслідків від настання потенційних ризикових подій матиме такий вигляд

$$
V_{\Sigma}^{D}=\sum_{i=1}^{M^{R}} v_{i}^{D}, \text { тис. грн. }
$$

Вважається нормою, якщо $V_{\Sigma}^{D}=(1,2 \ldots 1,4) \cdot V_{Z}^{R}$. Коли ж сумарна остаточна вартість розроблення ПЗ є більшою від початкової вартості проекту на 40 \% і більше, то потрібно запроваджувати заходи із запобігання чи знешкодження потенційних ризикових подій, про які йтиметься нижче (див. п. 3.1).

2.4. Встановлення рівня пріоритету пом'якшення та ранжування потениійних ризикових подій. Для встановлення рівня пріоритету пом'якшення та ранжування поточних ризикових подій знайдемо максимальний та мінімальний елементи множини $\tilde{\tilde{V}}^{o}$ з виразу (24).

Вважатимемо, що значення максимального елемента можна визначити за допомогою такого виразу $\max =\max \left\{v_{i j}^{O}, j=\overline{1, n_{i}^{R}}, i=\overline{1, M^{R}}\right\}$, для якого справедливе таке обмеження:

$$
\forall v_{i j}^{O} \in \tilde{\tilde{V}}^{O}, \max <v_{i j}^{O} \Rightarrow \max =v_{i j}^{O}, \forall j \in n_{i}^{R}, \forall i \in M^{R},
$$

де: $n_{i}^{R}-$ кількість потенційних ризикових подій розроблення ПЗ у $i$-ій множині; $M^{R}$ - кількість множин потенційних ризикових подій розроблення ПЗ. Водночас, значення мінімального елемента можна визначити за допомогою такого виразу $\min =\min \left\{v_{i j}^{O}, j=\overline{1, n_{i}^{R}}, i=\overline{1, M^{R}}\right\}$, для якого справедливе таке обмеження:

$$
\forall v_{i j}^{O} \in \tilde{\tilde{V}}^{O}, \min >v_{i j}^{O} \Rightarrow \min =v_{i j}^{O}, \forall j \in n_{i}^{R}, \forall i \in M^{R} .
$$

Маючи максимальне та мінімальне значення елементів множини $\tilde{\tilde{V}}^{o}$, отримаємо розмах інтервалу значень їі елементів [min; max], який поділимо на три однакові підінтервали:

$[\min ; \min +\Delta),[\min +\Delta ; \min +2 \cdot \Delta),[\min +2 \cdot \Delta ; \max ),($ де: $\Delta=(\max -\min ) / 3$.

Введемо таку множину рівнів пріоритетів реагування на потенційні ризикові події розроблення ПЗ

$$
\tilde{\tilde{P}}^{O}=\left\{\tilde{P}_{i}^{O}=\left\{p_{i j}^{O} \in\{1,2,3\}, j=\overline{1, n_{i}^{R}}\right\}, i=\overline{1, M^{R}}\right\},
$$

де $p_{i j}^{o}$ - рівень пріоритету реагування на $j$-ту потенційну ризикову подію 3 -ої їх множини (1 - низький, 2 - середній та 3 - високий відповідно рівень).

3 урахуванням (29) сформуємо такі правила встановлення рівня пріоритету реагування на потенційну ризикову подію розроблення ПЗ: 
1) якщо $\left(v_{i j}^{O} \geq \min \right) \wedge\left(v_{i j}^{O}<\min +\Delta\right)$, то рівень пріоритету реагування на ризикову подію $p_{i j}^{O}=1-$ низький, де $\forall j \in n_{i}^{R}, \forall i \in M^{R}$;

2) якщо $\left(v_{i j}^{O} \geq \min +\Delta\right) \wedge\left(v_{i j}^{O}<\min +2 \cdot \Delta\right)$, то рівень пріоритету реагування на ризикову подію $p_{i j}^{o}=2-$ середній, де $\forall j \in n_{i}^{R}, \forall i \in M^{R}$;

3) якщо $\left(v_{i j}^{O} \geq \min +2 \cdot \Delta\right) \wedge\left(v_{i j}^{O} \leq \max \right)$, то рівень пріоритету реагування на ризикову подію $p_{i j}^{o}=3-$ високий, де $\forall j \in n_{i}^{R}, \forall i \in M^{R}$
Внаслідок застосування наведених вище правил встановлення пріоритетів реагування на ризикові події розроблення ПЗ стосовно потенційних ризиків реалізації програмного проекту маємо набір $\forall p_{i j}^{o}=3, p_{i j}^{o} \in \tilde{\tilde{P}}^{O}$ першочергових ризиків, набір $\forall p_{i j}^{O}=2, p_{i j}^{o} \in \tilde{\tilde{P}}^{O}$ поточних ризиків і набір $\forall p_{i j}^{O}=1, p_{i j}^{O} \in \tilde{\tilde{P}}^{O}$ мало важливих ризиків, на які членам проектного колективу не варто звертати увагу при обранні заходів із зменшення або усунення потенційних ризикових подій.

\footnotetext{
Eтап 1. Іаентифікашія ризиків розроблення П3 Етап 2.Аналіз ризиків розроблення П3 Етап 3. Планування ризиків розроблення П3
}

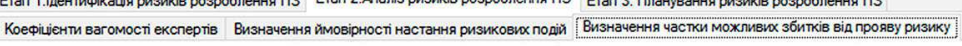

Розподіл вартості реалізації проекту за множинами настання потенційних ризикових подій

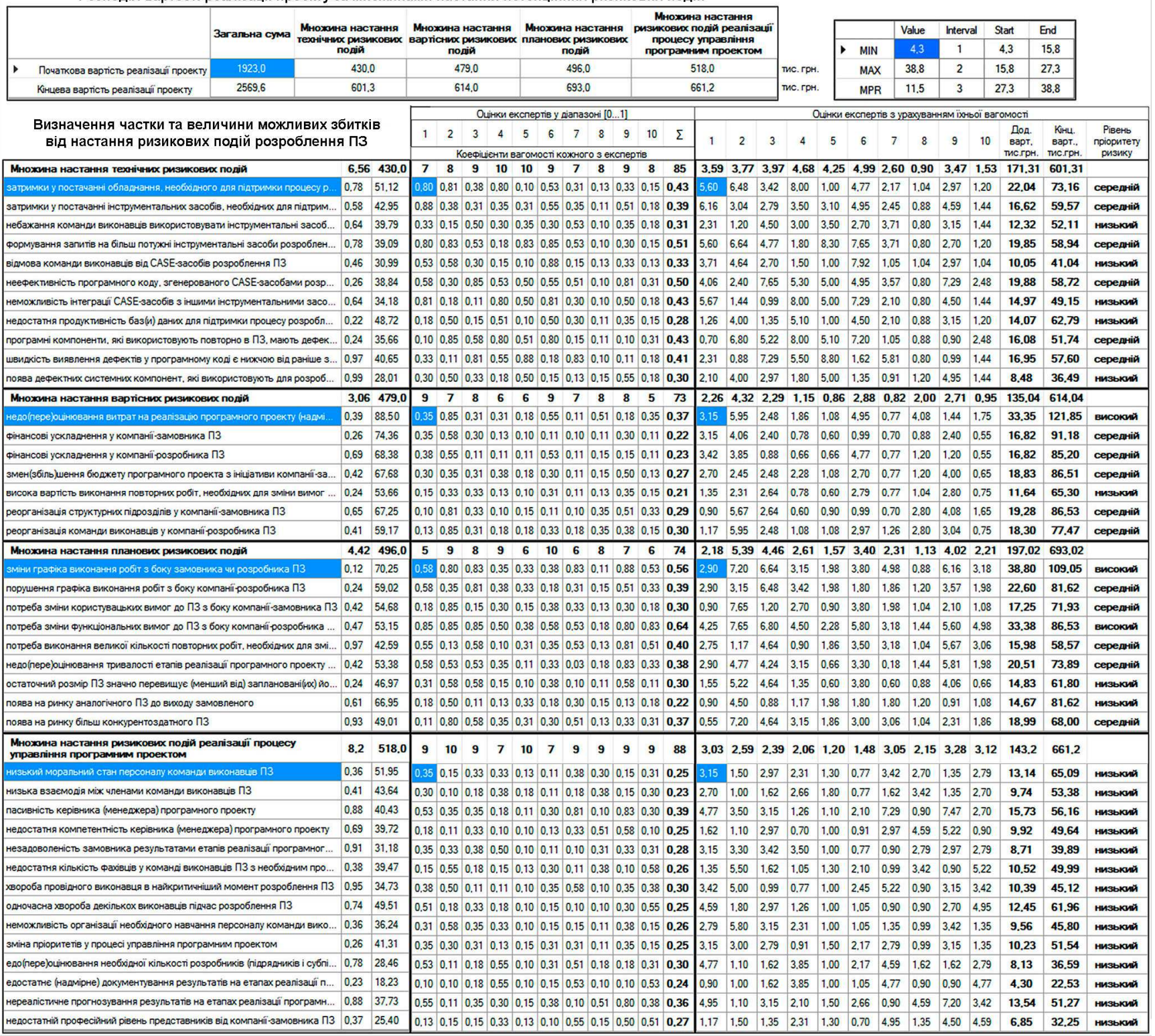

Рис. 6. Форма для визначення частки та величини можливих збитків від настання потенційних ризикових подій

На рис. 6 наведено результати визначення частки та величини можливих збитків від настання потенційних ризикових подій.

Отже, згідно з результатами аналізу провідних галузевих публікацій, розроблено такі формалізовані моделі: визначення ймовірності настання потенційних ризикових подій; розподілу вартості реалізації програмного проекту за множинами потенційних ризикових подій; визначення частки та величини можливих збитків від настання потенційних ризикових подій (математичне сподівання збитку); встановлення пріоритетів пом'якшення та ранжування потенційних ризикових подій. Також сформовано правила встановлення пріоритетів реагування на потенційну ризикову подію розроблення ПЗ.

Eman 3. Планування ризиків розроблення ПЗ. Під час планування ризиків необхідно їх, насамперед, ідентифікувати, оцінити стосовно можливих збитків, запровадити заходи щодо усунення чи пом'якшення ризиків. 
Для цього застосовують такі методи, як побудова дерева рішень або моделювання процесів, зазвичай, стохастичних. На цьому ж етапі визначають правила і політику реалізації програмного проекту та причини його припинення. При плануванні ризиків розроблення ПЗ варто враховувати й унікальні ризики в області програмної інженерії. Позаяк всі вони переважно стосуються реалізації програмного проекту, то необхідно з'ясувати, як саме цим проектом потрібно управляти, в т.ч. й ризиками його реалізації, а також визначити поточний план дій - звітність, моніторинг і контроль. На етапі планування також розглядають питання управління контрактами 3 постачальниками готових продуктів проекту, замовлених у підрядників, чи придбаних програмно-апаратних засобів, потрібних для успішної реалізації проекту.

При виконанні процесу планування ризиків розроблення ПЗ необхідно: проаналізувати, узгодити, виправити і затвердити користувацькі вимоги до ПЗ; створити перелік робіт з описом модулів ПЗ та їхніх компонент; визначити необхідні ресурси - людські та програмно-технічні; зробити деталізацію плану виконання робіт, для графічного подання яких потрібно збудувати діаграму Ганта.

Отже, фактично на цьому етапі й відбувається управління ризиками розроблення ПЗ. Тобто, для кожного ризику з переліку критичних необхідно виробити стратегію, яка хоча й не убезпечить проект від нього, однак зведе до мінімуму можливі збитки від його настання. Можна використати такі стратегії управління ризиками розроблення ПЗ:

- передача (англ. Transfer) - переносимо відповідальність за наслідки настання ризикових подій на третю сторону (замовника, компанію-партнера, страхову компанію і т.д.). Застосовувати цю стратегію можна тоді, якщо керівник проекту не може вплинути на ризикову подію, однак $є$ на кого цю відповідальність перекласти;

- прийняття (англ. Accept) - приймаємо відповідальність за наслідки настання ризикових подій на себе, але нічого не робимо, залишаємо все як $є$ без змін. Застосовувати цей підхід можна тоді, коли керівник проекту не може нічого вдіяти 3 ризиком, а робити передачу на третю сторону невиправдано дорого. Також цей підхід годиться й тоді, коли ризикова подія є незначною, тобто збитки від неї мінімальними;

- пом'якшення (англ. Mitigate) - боремося з ризиками розроблення ПЗ різними методами і засобами, приймаючи відповідальність за їх наслідки на себе. Для боротьби з такими ризиками добре мати декілька планів, однак основний та відхідний є обов'язковими.

Основний план - призначений для того, щоб наслідки від настання ризикових подій якщо не усунути, то хоча б пом'якшити чи зменшити. Його необхідно впроваджувати відразу, ще до того як ризикова подія відбулася. Керівник проекту повинен знижувати або ймовірність їі появи, або наслідки від її настання. Тут керівнику проекту допоможе запис ризиків у форматі "причина-ризик-ефект". Щоб знизити ймовірність настання ризикових подій, потрібно боротися з причиною їх появи. Щоб успішно ліквідувати наслідки від їх настання, потрібно захищати об'єкт небезпеки від їхнього впливу.

Вiдxiдний план - розробляють на випадок, якщо ризикова подія все-таки відбудеться та, як наслідок, негативно вплине на хід реалізації програмного проекту. Цей план потрібно впроваджувати у тому випадку, якщо заходи щодо боротьби з ризиками реалізації ПЗ не принесли сподіваних результатів, тобто їх уникнення, а настання ризикової події стане черговою проблемою команди-розробників ПЗ. Для продовження роботи над проектом потрібно, насамперед, локалізувати ризикову подію від іiі розповсюдження та розвитку, зосередити сили і засоби на ліквідацію наявних збитків і подальших наслідків, посилити контроль як за побічними ефектами, так і за новими загрозами. Для цього потрібно мати в наявності завчасно розроблені відповідні стратегії дій для швидкого і ефективного їх виконання.

3.1. Заходи із запобігання чи знешкодження ризиків. Важливо відзначити, що всі величини, пов'язані із ризиком, не $\epsilon$ постійними в програмному проекті. Ймовірність настання ризикової події та можливі збитки від неї можуть зростати та спадати внаслідок застосування заходів із зменшення або усунення ризиків. Тому потрібні показники для оцінювання ймовірності настання ризикових подій, їхньої величини збитку від них після застосування таких заходів.

На підставі провідних галузевих публікацій (Alferov, 2008; Braude, 2004; Fatrell, Shafer \& Shafer, 2003; Sommervill, 2002; Zyl, 2010) сформуємо множину потенційних заходів із зменшення або усунення ризикових подій:

$$
\tilde{Z}^{R}=\left\{z_{u}^{R}=\left\{z_{u}^{\min }, z_{u}^{\max }, z_{u}^{\mu}\right\}, u=\overline{1, N^{R}}\right\},
$$

де: $z_{j}^{R}$ - назва $u$-го потенційного заходу із зменшення або усунення ризикових подій; $z_{u}^{\min }, z_{u}^{\max }-$ мінімальне й максимальне значення знаходження $u$-ої неперервної випадкової величини; $z_{u}^{\mu}$ - математичне сподівання ймовірності зменшення або усунення ризикових подій від запровадження $u$-го потенційного заходу; $N^{R}-$ кількість заходів із зменшення або усунення ризикових подій.

В табл. 2 наведено назви потенційних заходів із запобігання чи знешкодження ризикових подій, інтервал знаходження неперервної випадкової величини за логнормальним законом розподілу і іiі математичне сподівання $(\mu)$. Дані взято з різних літературних джерел, а також 3 власних досліджень, отриманих під час виконання різних проектів (Hrytsiuk \& Zhabych, 2018). 3розуміло, ці дані можуть бути дещо уточнені різними фахівцями під час виконання аналогічних робіт.

Нагадаємо, логнормальний розподіл у теорії ймовірностей - двопараметричне сімейство абсолютно неперервних розподілів, у яких присутня неперервна випадкова величина. Якщо випадкова величина має логнормальний розподіл, то їі логарифм має нормальний розподіл. Логнормальний розподіл характеризується двома параметрами: $\mu>0$ - математичне сподівання, $\sigma^{2}-$ дисперсія випадкової величини. Параметр $\sigma>0$ також відомий як стандартне відхилення.

Зазвичай, процедура запровадження будь-якого 3 потенційних заходів із зменшення або усунення ризикових подій (табл. 2) передбачає відповідне фінансування різного обсягу. Наприклад, вартість реалізації деяких заходів може залежати від кількості членів проектного колективу, які проходитимуть відповідний тренінг $\left(z_{8}^{R}\right)$, від кількості залучених експертів для надання відповідних консультацій ( $z_{6}^{R}$ чи $\left.z_{7}^{R}\right)$ чи вартості придбання більш продуктивної бази даних $\left(z_{15}^{R}\right)$ тощо. Такі додаткові витрати можуть входити в кошторис витрат на реалізацію поточного проекту, або можуть бути рівномір- 
но розподілені між різними проектами, які виконувались в поточному році. Пов'язано це з тим, що результати запровадження будь-якого заходу діють на команду розробників ПЗ не короткотерміново, а протягом трива- лого періоду, зазвичай від 3 до 5 років. У будь-якому випадку вони дещо зменшуватимуть чисті прибутки компанії-розробника ПЗ.

Табл. 2. Потенційні заходи із запобігання чи знешкодження ризикових подій

\begin{tabular}{|c|c|c|c|}
\hline $\begin{array}{l}\text { № } \\
\Pi / \Pi\end{array}$ & Назва потенційного заходу & $\begin{array}{l}\text { Інтервал } \\
\text { розподілу }\end{array}$ & $\mu$ \\
\hline$z_{1}^{R}$ & попереднє навчання членів проектного колективу & $0,07 \ldots 0,19$ & 0,12 \\
\hline$z_{2}^{R}$ & узгодження детального переліку користувацьких вимог до ПЗ із замовником & $0,08 \ldots 0,16$ & 0,11 \\
\hline$z_{3}^{R}$ & внесення узгодженого переліку користувацьких вимог до ПЗ замовника в договір на виконання проекту & $0,10 \ldots 0,24$ & 0,15 \\
\hline$z_{4}^{R}$ & точне слідування вимогам замовника з узгодженого переліку користувацьких вимог до ПЗ & $0,05 \ldots 0,22$ & 0,10 \\
\hline$z_{5}^{R}$ & попередні дослідження ринку наявного ПЗ та його функціональних можливостей & $0,15 \ldots 0,25$ & 0,18 \\
\hline$z_{6}^{R}$ & експертна оцінка програмного проекту досвідченим стороннім консультантом & $0,09 \ldots 0,23$ & 0,13 \\
\hline$z_{7}^{R}$ & консультації досвідченого стороннього експерта під час реалізації програмного проекту & $0,14 \ldots 0,21$ & 0,17 \\
\hline$z_{8}^{R}$ & тренінг проектного колективу з вивчення сучасних інструментів розроблення ПЗ & $0,08 \ldots 0,16$ & 0,12 \\
\hline$z_{9}^{R}$ & укладання договору страхування ризикових подій & $0,12 \ldots 0,19$ & 0,14 \\
\hline$z_{10}^{R}$ & $\begin{array}{l}\text { використання "шаблонних" рішень з вдалих попередніх програмних проектів при управлінні ризиками } \\
\text { розроблення ПЗ }\end{array}$ & $0,06 \ldots 0,20$ & 0,12 \\
\hline$z_{11}^{R}$ & $\begin{array}{l}\text { підготовка документів, які показують важливість даного проекту для досягнення фінансових цілей ком- } \\
\text { панії-розробника }\end{array}$ & $0,11 \ldots 0,15$ & 0,13 \\
\hline$z_{12}^{R}$ & $\begin{array}{l}\text { реорганізація роботи проектного колективу так, щоб обов'язки та робота його членів перекривали один } \\
\text { одного }\end{array}$ & $0,08 \ldots 0,17$ & 0,11 \\
\hline$z_{13}^{R}$ & замовлення частини компонент розроблюваного ПЗ в компаній-підрядників & $0,11 \ldots 0,21$ & 0,16 \\
\hline$z_{14}^{R}$ & $\begin{array}{l}\text { заміна потенційно дефектних компонент розроблюваного ПЗ придбаними в інших компаній-розробни- } \\
\text { ків, які гарантують якість їхньої роботи }\end{array}$ & $0,08 \ldots 0,20$ & 0,13 \\
\hline$z_{15}^{R}$ & придбання більш продуктивної бази даних з можливістю наповнення бази знань власною інформацією & $0,04 \ldots 0,25$ & 0,11 \\
\hline $\begin{array}{l}z_{16}^{R} \\
\end{array}$ & використання сучасних генераторів програмного коду з можливістю його адаптації до архітектури П3 & $0,06 \ldots 0,22$ & 0,12 \\
\hline$z_{17}^{R}$ & $\begin{array}{l}\text { реорганізація роботи проектного колективу залежно від рівня труднощів виконання завдань та їхніх } \\
\text { професійних навиків }\end{array}$ & $0,02 \ldots 0,20$ & 0,10 \\
\hline$z_{18}^{R}$ & $\begin{array}{l}\text { повторне використання придатних компонент ПЗ, які були розроблені раніше для інших програмних } \\
\text { проектів }\end{array}$ & $0,11 \ldots 0,19$ & 0,16 \\
\hline$z_{19}^{R}$ & аналіз причин доцільності розроблення даного ПЗ & $0,08 \ldots 0,17$ & 0,13 \\
\hline
\end{tabular}

3.2. Визначення ймовірності зменшення або усунення ризикових подій. Варто зазначити, що процес запровадження заходів зі зменшення або усунення ризиків розроблення ПЗ є ітераційним. Він передбачає спочатку процедуру реагування на потенційні ризикові події 3 високим рівнем пріоритету шляхом зниження їх до середнього значення, а потім, за потреби, можна понизити деякі середні рівні пріоритету. Зрозуміло, пом'якшувати усі середні рівні пріоритету - не варто, позаяк вважається нормою, якщо сумарна остаточна вартість розроблення ПЗ є більшою від початкової вартості проекту до 40 \% (див. п. 2.3).

Для визначення ймовірності зменшення або усунення ризикових подій потрібно залучити до процедури розрахунку такі вхідні дані. У п. 2.4 було визначено множину рівнів пріоритетів реагування на потенційні ризикові події розроблення ПЗ, тобто використаємо вираз (30). Окрім цього, у п. 2.1 було визначено усереднені значення ймовірності настання потенційних ризикових подій розроблення ПЗ відповідної множини з урахуванням кваліфікації відповідних експертів, де використаємо вираз (17).

Отже, з врахуванням виразів (17) і (30) введемо правила визначення заходів із зменшення або усунення ризиків реалізації конкретного програмного проекту. В кожному правилі передбачимо тільки один, найбільш придатний $з$ точки зору керівника проекту, захід для зменшення або усунення кожного потенційного ризику.
Якщо рівень пріоритету реагування на потенційні ризикові події становить $p_{i j}^{O}=3 \vee 2$ для $\forall j \in n_{i}^{R}, \forall i \in M^{R}$, то відповідна ймовірність настання потенційної ризикової події $g_{i j}^{P}$ може бути зменшена або усунута за допомогою такого заходу:

$$
g_{i j}^{\prime P}=g_{i j}^{P} / 100-z_{u}^{\mu}, z_{u}^{\mu} \in \tilde{Z}^{R}, \forall u \in N^{R}, \%,
$$

де: $g_{i j}^{\prime P}$ - уточнене значення ймовірності настання $j$-ої ризикової події для $i$-ої їх множини. Тоді, внаслідок застосування наведених вище правил, матимемо таку множину заходів із зменшення або усунення ризиків розроблення ПЗ для конкретного програмного проекту в 1ій ітерації

$$
\tilde{\tilde{G}}^{P P}=\left\{\tilde{G}_{i}^{\prime P}=\left\{g_{i j}^{\prime P} \cdot 100, j=\overline{1, n_{i}^{R}}\right\}, i=\overline{1, M^{R}}\right\}, \%,
$$

водночас як у 2-ій ітерації ця множина матиме такий вигляд

$$
\tilde{\tilde{G}}^{\prime \prime P}=\left\{\tilde{G}_{i}^{\prime \prime P}=\left\{g_{i j}^{\prime \prime P} \cdot 100, j=\overline{1, n_{i}^{R}}\right\}, i=\overline{1, M^{R}}\right\}, \%
$$

і т.д. Як після 1-ої, так і після 2-ої та інших ітерації потрібно провести нові розрахунки, починаючи з п. 2.1 і завершуючи п. 2.4. За потреби, також потрібно задіяти ще й п. 3.2, якщо рівні пріоритетів реагування на потенційні ризикові події є ще високими, тому є потреба перейти до виконання наступної ітерації.

На рис. 7 наведено заходи із зменшення або усунення ризику. 


\begin{tabular}{|c|c|c|c|c|c|}
\hline \multicolumn{2}{|l|}{ Назва заходів } & Пом'якшення & Прийняття & Ууилення & Передача \\
\hline \multicolumn{2}{|l|}{ узгодхення детального переліку вимог до ПЗ із замовником } & 19.83 & 19.89 & 19,87 & 19.81 \\
\hline \multicolumn{2}{|l|}{ Внесення узгодженого переліку вимог до П3 замовника в договір } & 10.02 & 10,06 & 10,03 & 10,04 \\
\hline \multicolumn{2}{|l|}{ точне слідування вимогам замовника з узгодженого переліку вимог до ПЗ } & 19.85 & 19.86 & 19.83 & 19.88 \\
\hline \multicolumn{2}{|l|}{ попередні дослірхення ринку } & 14.92 & 14.95 & 14.94 & 14.92 \\
\hline \multicolumn{2}{|l|}{ експертна оцинка програмного проекту досвірченим стороннім консупьтантом } & 14,06 & 14.03 & 14,00 & 14,05 \\
\hline \multicolumn{2}{|l|}{ Консультацї досвідченого стороннього консультанта } & 16.08 & 16.09 & 16.09 & 16.03 \\
\hline \multicolumn{2}{|l|}{ тренінг з вивчення необхонних інструментів розроблення ПЗ } & 16.96 & 16.99 & 16.91 & 16.90 \\
\hline \multicolumn{2}{|l|}{ укладання договору страхування } & 8.44 & 8.42 & 8.49 & 8.42 \\
\hline \multicolumn{2}{|l|}{ використання мшаблоннихи рішень з вдалих попереднік проектів при управлінні програмним проектом } & 33.39 & 33.35 & 33.30 & 33.34 \\
\hline \multicolumn{2}{|c|}{ Пиірготовка документів, які показують важливість даного проекту для досягнення фінансових шілей компаниі розробника } & 16.84 & 16.88 & 16,84 & 16,87 \\
\hline \multicolumn{2}{|c|}{ реорганізашія роботи проектного колективу так, щоб обов'язки та робота членів колективу перекривапи один одного } & 16.85 & 16.84 & 16.86 & 16.87 \\
\hline \multicolumn{2}{|c|}{ придбання (замовлення) частини компонент розроблюваного ПЗ } & 18.81 & 18.87 & 18.80 & 18.88 \\
\hline \multicolumn{2}{|c|}{ заміна потенційно дефекпикх компонент розроблюваного ПЗ придбаними компонентами. які гарантують якість викона... } & 11.67 & 11.67 & 11.62 & 11.63 \\
\hline \multicolumn{2}{|c|}{ придбання більш продуктивної бази даних } & 19.20 & 19.21 & 19.23 & 19.27 \\
\hline \multicolumn{2}{|l|}{ використання генератора програмного коду } & 18.6 & 18.2 & 18.8 & 18.2 \\
\hline \multicolumn{2}{|c|}{ реорганізація роботи проектного колективу залежжо від рівня труднощів виконання завдань та професійник рівнів розр... } & 38.5 & 38.7 & 38.1 & 38.5 \\
\hline \multicolumn{2}{|c|}{ повторне використання приданних компонент ПЗ. які були розроблені аля інших програмних проектів } & 22.1 & 22.2 & 22.5 & 22.4 \\
\hline \multicolumn{2}{|l|}{ аналіз дочильності розроблення даного ПЗ. } & 17.20 & 17.22 & 17.29 & 17.29 \\
\hline \multicolumn{5}{|l|}{ 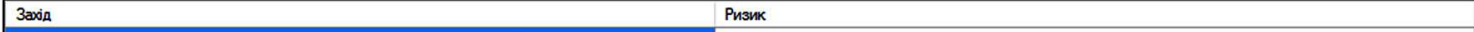 } & Тип усунення \\
\hline \multicolumn{5}{|l|}{ точне слідування вимогам замовника з узгодженого переліку вимог до П3 } & Пом'якшення \\
\hline \multirow{2}{*}{\begin{tabular}{|l} 
консультаиі досвідченого стороннього консультанта \\
тонне слідування вимогам замовника з узгодженого переліку вимог до П3
\end{tabular}} & \multicolumn{4}{|c|}{ програмні компоненти, які використовують повторно в ПЗ. мають дефекти та обмехені функціональні мох... } & Пом'якшенняя \\
\hline & \multicolumn{4}{|c|}{ неефективність програмного коду. згенерованого CASE-засобами розробпення ПЗ } & Передача \\
\hline $\begin{array}{l}\text { точне слірування вимогам замовника з узгодженого переліку вимог до ПЗ } \\
\text { використання жшаблонникж рішеньь з вдалих попереднік проектів при управлінні програмним проектом }\end{array}$ & и недо(пере)оинюва & на реanisa & роекту (нан & & Прийняття \\
\hline
\end{tabular}

Рис. 7. Форма для встановлення заходів із зменшення або усунення ризиків розроблення ПЗ

Отже, згідно з результатами аналізу провідних галузевих публікацій, уточнено заходи із запобігання чи знешкодження ризиків розроблення ПЗ, а також запропоновано методику визначення ймовірності зменшення або усунення ризикових подій. Також сформовано правило визначення заходів із зменшення або усунення ризиків реалізації конкретного програмного проекту.

Eman 4. Моніторинг ризиків розроблення ПЗ. Це швидше за все процес, а ніж етап, мета якого підтримувати в актуальному стані перелік ідентифікованих ризиків розроблення ПЗ і план реалізації програмного проекту з врахуванням різних ризикових подій.

Моніторинг - це досить складний та неоднозначний процес, який можна використовувати для різних цілей та в різних масштабах, але при цьому він може мати спільні ознаки. Проведений аналіз (Pozhar, 2009) поняття "моніторинг" у різних наукових джерелах дає підставу стверджувати, що чіткого визначення й однозначного трактування цієї категорії не існує, особливо в інженерії ПЗ. Пов'язано це з тим, що моніторинг належить як до наукової, так і до практичної сфери діяльності людини. Його можна розглядати як засіб для дослідження реальності, так і метод, який забезпечує процес управління своєчасною, достовірною та якісною інформацією. У сучасних наукових словниках найбільш поширене таке визначення цього поняття: "Моніторинг це постійне спостереження за будь-яким процесом з метою виявлення його відповідності бажаному результату або первісне припущення - спостереження, оцінювання й прогнозування стану довкілля у зв'язку з діяльністю людини" (Kolesnikov, 2007).

На думку В. К. Галіцина, моніторинг - це безупинне спостереження за економічними (або будь-якими іншими) об'єктами, проведення аналізу їхньої діяльності як складової процесу управління будь-яким підприємством чи організацією. Отже, у широкому розумінні моніторинг $є$ функцією процесу управління (теж у широкому розумінні) (Galitsyn, 2001).

На думку С. В. Устенко, моніторинг - це систематичне збирання та оброблення інформації, яку можна безпосередньо використати для покращення процедури прийняття управлінських рішень або опосередковано для інформування суспільства про стан будь-якої ситуації (економічної, політичної тощо), а також прямо як інструмент зворотного зв'язку з метою реалізації проектів оцінювання програм і розроблення політики повсякденної діяльності (Ustenko, 2003).

Отже, моніторинг загалом - це комплексна система спостереження, збирання, оброблення, систематизації та аналізу інформації про стан деякого об'єкта, яка дає йому об'єктивну оцінку і прогнозує його зміни, розробляє обгрунтовані рекомендації щодо прийняття управлінських рішень (Edronova \& Kavinov, 2005).

Як зазначає Д. Е. Плісецький, моніторинг - це спеціально організоване систематичне спостереження за станом об'єктів, процесів і явищ з метою їх оцінювання, контролю або прогнозування змін (Plisetsky, 2004).

3 цих визначень видно, що моніторинг не обмежується тільки спостереженням за процесом функціонування певного об'єкта, а навпаки - $\epsilon$ ефективною координаційною системою забезпечення взаємозв'язку між процедурами формування інформаційної бази даних, ідентифікацією та оцінюванням стану цього об'єкта і процедурою прийняття відповідних управлінських рішень, що забезпечать його стабільне функціонування.

Роботи багатьох науковців (Ustenko, 2003; Plisetsky, 2004), які досліджували моніторинг у сфері управління процесом розроблення ПЗ, вказують на різні визначення цього поняття. Вважаємо (Hrytsiuk \& Zhabych, 2018; Zhabych \& Hrytsiuk, 2018; Hrytsiuk \& Dalyavskyy, 2018), що моніторинг ризиків розроблення ПЗ - це:

- інформаційна система, яка постійно доповнюється актуальною інформацією завдяки безупинності (системності) відстеження стану етапів реалізації програмного проекту. Це процес цілеспрямованого підбору відповідних інформаційних показників, необхідних для адекватного оцінювання та грунтовного аналізу цього стану, а також підготовки й прийняття ефективних рішень під час управління ризиками розроблення ПЗ;

- система відстеження відповідності рівня настання ризикових подій критеріям, встановленим політикою діяльності IT-компанії, внаслідок чого забезпечується реалізація та перевірка стану об'єкта, перегляд та зміна цілей управління ризиками розроблення ПЗ;

- координаційна система забезпечення зв'язку між процедурами формування інформаційної бази даних, їх ідентифікацією та аналізом, оцінюванням і контролем, а також регулюванням заходів зі зменшення чи усунення ризиків розроблення ПЗ в IT-компанії. 
Отже, моніторинг ризиків розроблення ПЗ - це інформаційна система, яка за: процесом реалізації - створення умов для прийняття ефективних управлінських рішень щодо запровадження заходів зі зменшення та усунення різних ризикових подій; за результативністю технологія оцінювання фактичного стану етапів реалізації програмного проекту, регулювання їхнього стану залежно від наслідків настання різних ризикових подій і прогнозування подальших змін. 3 організаційної точки зору моніторинг - це система 3 певним набором таких елементів, як мета, об'єкт, суб'єкт і механізм реалізації.

Мета моніторингу ризиків розроблення ПЗ полягає у визначенні прогнозованих значень ймовірності настання ризикових подій через інформаційно-аналітичне забезпечення та прийняття адекватних управлінських рішень учасниками процесу ризик-менеджменту щодо запровадження заходів зі зменшення та усунення ризикових подій. Все це спрямоване на узгодження дій керівництва IT-компанії з командами розробників ПЗ для досягнення запланованого співвідношення "дохідністьризик".

Об'єктом моніторингу ризиків розроблення ПЗ є:

1) відстеження зовнішніх i внутрішніх чинників, які сприяють виникненню різних ризикових подій;

2) зміна моделі діяльності проектного менеджменту загалом і моделі поведінки керівника проекту зокрема на різних етапах реалізації програмного проекту;
3) встановлення фактичної позиції IT-компанії на ринку ПЗ, тобто деякої масштабованої величини, що відображає іiі можливість запровадити ефективні заходи щодо запобігання чи знешкодження ризиків розроблення ПЗ. Дієвість цих заходів можна визначити в абсолютних величинах, зазвичай грошовому еквіваленті, або відносних величинах за відношенням до використаних власних методів і засобів, а також професіоналізму команди розробників ПЗ.

Фактична позиція IT-компанії на ринку ПЗ може належати до одного з трьох типів:

- стратегічна позиція, що формується внаслідок трансформації короткотермінових поодиноких заходів у довготермінову систему заходів із запобігання та знешкодження ризиків розроблення ПЗ;

- тактична позиція, яка $є$ наслідком залучення та внесення коштів у систему заходів із запобігання та знешкодження ризиків розроблення ПЗ у вигляді постійних відрахувань від кожного програмного проекту;

- бізнес-позииія, що формується внаслідок запровадження конкурентних дій чи дієвих поточних операцій на ринку ПЗ шляхом використання сучасних високоефективних програмних інструментів чи технологій розроблення ПЗ.

Суб'єкти моніторингу ризиків розроблення ПЗ визначає загальна система ризик-менеджменту в IT-компанії (Pozhar, 2009; Ustenko, 2003), узагальнена характеристика яких наведена в табл. 3.

Механізм реалізації моніторингу ризиків розроблення ПЗ наведено на рис. 8.

Табл. 3. Розподіл функцій моніторингу в межах організаційної структури системи управління ризиками розроблення П3

\begin{tabular}{|c|c|}
\hline Суб'єкт управління & Функції в системі моніторингу ризиків розроблення ПЗ \\
\hline Спостережна рада & $\begin{array}{l}\text { Визначення стратегічних орієнтирів і програмних цілей у сфері управління ризиками розроблення } \\
\text { П3, що підлягають моніторингу }\end{array}$ \\
\hline Керівництво IT-компанії & Забезпечення стратегічного моніторингу ризиків розроблення ПЗ в ІТ-компанії \\
\hline $\begin{array}{l}\text { Комітет з управління сис- } \\
\text { темою заходів із запобіган- } \\
\text { ня та знешкодження ризи- } \\
\text { ків (КУСЗ) }\end{array}$ & $\begin{array}{l}\text { Моніторинг реалізації стратегії діяльності ІТ-компанії, оцінювання динаміки основних іії показни- } \\
\text { ків, розгляд та аналіз відповідних положень і лімітів, оцінювання позиції керівництва IT-компанії } \\
\text { щодо прийнятних ризиків розроблення ПЗ, вибір заходів зі зменшення та усунення ризикових по- } \\
\text { дій, підготовка висновків для керівництва, директив і наказів підпорядкованим підрозділам }\end{array}$ \\
\hline $\begin{array}{l}\text { Експертна рада } \\
\text { ІТ-компанії }\end{array}$ & $\begin{array}{l}\text { Регулювання ризиків розроблення ПЗ, додержання лімітів наявних ресурсів (у т.ч. й людських), } \\
\text { затверджених КУСЗ, встановлення базових рівнів настання ризикових подій для децентралізова- } \\
\text { них структур, короткотермінові угоди з підрядниками та операції з постачальниками, дослідження } \\
\text { ринку наявного ПЗ, фінансовий інжиніринг для VIP-клієнтів }\end{array}$ \\
\hline $\begin{array}{l}\text { Підрозділ } \\
\text { ризик-менеджменту }\end{array}$ & $\begin{array}{l}\text { Оцінювання та аналіз різних ризикових подій, розроблення адекватної методики запобігання та } \\
\text { знешкодження ризиків розроблення ПЗ, ідентифікація та оцінювання можливих порушень рівня } \\
\text { настання ризикових подій, винесення рекомендацій керівництву IT-компанії щодо подальшої так- } \\
\text { тики роботи з ризиками та негативними наслідками від їх настання }\end{array}$ \\
\hline $\begin{array}{l}\text { Фінансово-аналітична } \\
\text { служба }\end{array}$ & $\begin{array}{l}\text { Збирання, фіксація, оброблення та систематизація первинної інформації від наслідків настання ри- } \\
\text { зикових подій, аналіз наявних збитків і прогнозування потенційних втрат, структурування та фор- } \\
\text { мування відповідних звітів керівництву ІТ-компанії та її інвесторам }\end{array}$ \\
\hline Інформаційний відділ & $\begin{array}{l}\text { Інформаційна підтримка процесу управління ризиками розроблення ПЗ, створення та супровід сис- } \\
\text { теми заходів із запобігання та знешкодження ризиків розроблення ПЗ }\end{array}$ \\
\hline $\begin{array}{l}\text { Служба внутрішнього } \\
\text { контролю }\end{array}$ & $\begin{array}{l}\text { Оцінювання якості та ефективності: запроваджених заходів зі зниження та усунення ризикових по- } \\
\text { дій; методів і засобів управління ризиками розроблення ПЗ; підтримки і ведення системи заходів із } \\
\text { запобігання та знешкодження ризиків розроблення ПЗ }\end{array}$ \\
\hline
\end{tabular}

Інформаційна система заходів із запобігання та знешкодження Управління ризиками ризиків розроблення ПЗ

розроблення ПЗ

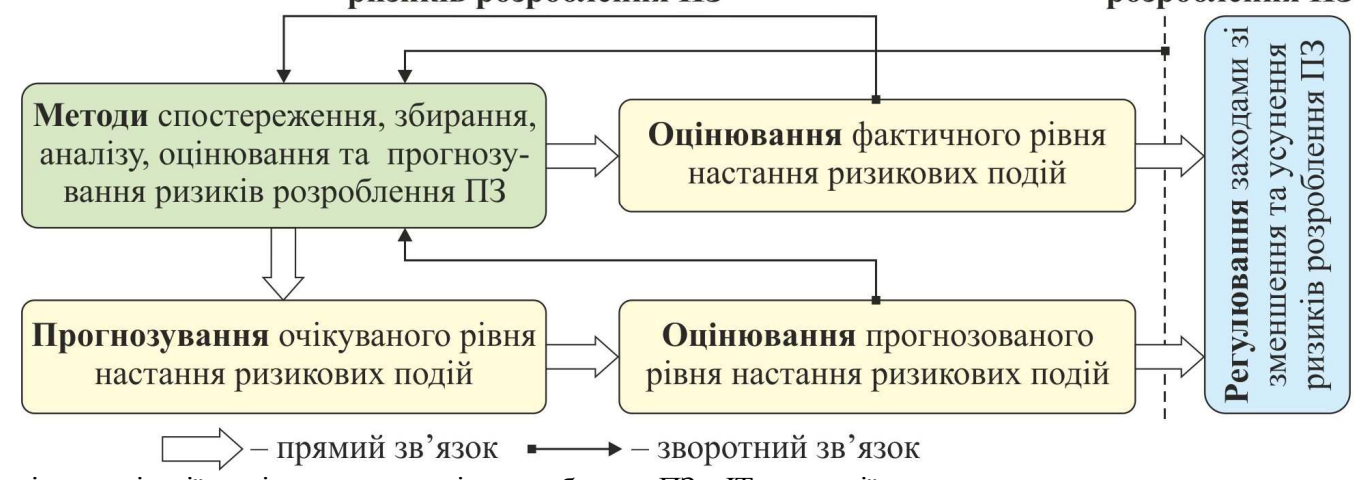

Рис. 8. Механізм реалізації моніторингу ризиків розроблення ПЗ в ІТ-компанії 
Важливою складовою механізму моніторингу ризиків розроблення ПЗ в ІТ-компанії виступає підсистема забезпечення (Pozhar, 2009), що містить такі блоки:

1) Технічне забезпечення:

- спеціалізоване ПЗ;

- засоби передачі даних;

- засоби захисту інформації;

- системи управління базами даних.

2) Інформаційне забезпечення:

- інформація із зовнішніх джерел - показники, що характеризують загальноекономічний розвиток країни та розвиток самої ІТ-компанії, а також кон'юнктуру ринку ПЗ;

- внутрішня інформація, що складається з обов'язкової, яка необхідна для звітування IT-компанії перед регулювальними органами чи інвесторами, та управлінської, яку самостійно формує IT-компанія для власних потреб.

3) Нормативне забезпечення:

- зовнішне - це система законодавчих і нормативних актів, що визначають вимоги до функціонування системи ризикменеджменту в IT-компанії;

- внутрішне - це система внутрішньої політики діяльності ІТ-компанії, відповідні положення та процедури, що регламентують процес управління ризиками розроблення ПЗ.

Отже, внаслідок аналізу провідних галузевих публікацій, уточнено поняття "моніторинг ризиків розроблення ПЗ", а також наведено власне визначення цього поняття. Встановлено, що з організаційної точки зору моніторинг ризиків розроблення ПЗ в IT-компанії є системою 3 певним набором елементів - мета, об'єкт, суб'єкт і механізм. Наведено їх пояснення, розподіл функцій моніторингу в межах організаційної структури системи управління ризиками розроблення ПЗ, механізм реалізації моніторингу, а також підсистема його забезпечення - технічна, інформаційна і нормативна.

Висновки. Розроблено методику формалізації процесу управляння ризиками розроблення ПЗ, яка дає змогу оцінити несприятливі ситуацій під час реалізації етапів програмного проекту, а також уможливлює розроблення стратегій і тактик їх передбачення, сприйняття та подолання негативних наслідків від їх прояву. За результатами дослідження можна зробити такі основні висновки.

1. З'ясовано, що управління ризиками розроблення ПЗ потрібно розглядати як процес, який дає змогу визначити особливості такого управління, основні категорії наявних ризиків, ризик-орієнтовний підхід до управління ними, а також уможливлює визначення прийнятного рівня ризику для успішного завершення (провалу) програмного проекту IT-компанією.

2. Проведено деталізацію та формалізовано процес управління ризиками розроблення ПЗ, що дало змогу оцінити несприятливі ситуацій під час реалізації етапів програмного проекту, забезпечило можливість розроблення стратегій і тактик їх передбачення та сприйняття, локалізацію та ліквідацію, а також уможливило подолання негативних наслідків від їх прояву.

3. Уточнено підходи до ідентифікації ризиків розроблення ПЗ, їхнього грунтовного аналізу, планування та моніторингу, що дало змогу поміняти модель діяльності проектного менеджменту загалом і змінити модель поведінки керівника проекту зокрема на різних етапах реалізації програмного проекту.
4. Удосконалено методику визначення можливих джерел появи ризиків розроблення ПЗ й ідентифікації потенційних ризикових подій, що дало змогу сформувати структуровану множину наявних ризиків реалізації програмних проектів і розробити їх формалізовані моделі для проведення відповідних розрахунків.

5. Розроблено методику визначення ймовірностей настання потенційних ризикових подій у відповідних їх множинах, запропоновано підхід до розподілу вартості реалізації програмного проекту за цими множинами загалом і потенційними ризиковими подіями зокрема, визначено частки та величини можливих збитків від настання ризикових подій, встановлено пріоритети їх пом'якшення та ранжування, що дало змогу проаналізувати ідентифіковані потенційні ризикові події розроблення ПЗ, проранжувати їх за пріоритетами реагування на них, а також уможливило розроблення їх формалізованих моделей.

6. Уточнено заходи із запобігання чи знешкодження ризиків розроблення ПЗ, удосконалено методику визначення ймовірності зменшення або усунення різних ризикових подій, що дало змогу визначити правила і політику реалізації програмного проекту, здійснити управління ризиками розроблення ПЗ, а також уможливило розроблення їх формалізованих моделей.

7. Уточнено поняття "моніторинг ризиків розроблення ПЗ", встановлено особливості його реалізації в IT-компанії з організаційної точки зору, що дало змогу визначити його як систему з певним набором таких елементів, як мета, об'єкт, суб'єкт і механізм реалізації, а також встановлено підсистему його забезпечення - технічну, інформаційну та нормативну.

8. Зроблено відповідні висновки та надано рекомендації щодо використання розробленої методики формалізації процесу управляння ризиками розроблення ПЗ.

\section{Перелік використаних джерел}

Alferov, P. (2008). The Role of a Business Customer in an IT-project. Project management, 4. Retrieved from: http://www.pmmagazine.ru/document.asp?ob no=771. [In Russian].

Bloch, M., Blumberg, S., \& Laartz, J. (2012, October). Delivering large-scale IT projects on time, on budget, and on value. Retrieved from:

http://www.mckinsey.com/insights/business technology/delivering largescale it projects on time on budget and on value

Borisov, A. N., Krumberg, O. A., \& Fedorov, I. P. (1990). Priniatie reshenii na osnove nechetkikh modelei: primery ispolzovaniia. Riga: Publishing House "Zinatne", 184 p. [In Russian].

Botsula, M. P., \& Morhun, I. A. (2014). Novyi metod ta informatsiina tekhnolohiia obroblennia danykh dlia upravlinnia yakistiu elektronnykh navchalnykh kursiv. Informatsiini tekhnolohii ta kompiuterna inzheneriia: mizhnarodnyi naukovo-tekhnichnyi zhurnal, 3, 25-33. Retrieved from: http://nbuv.gov.ua/UJRN/Itki 201436. [in Ukrainian].

Braude, E. Dzh. (2004). Software Development Technology. SanktPetersburg: Publishing House "Peter". 655 p. [In Russian].

CHAOS Manifesto. (2013). Think Big, Act Small. Retrieved from: http://www.versionone.com/assets/img/files/CHAOSManifesto201 3.pdf

DeMarco Tom. (2002). Controlling Software Projects: Management, Measurement and Estimation. 279 p.

DeMarko, T., \& Lister, T. (2005). Valsiruia s medvediami: upravlenie riskami $v$ proektakh po razrabotke programmnogo obespecheniia. Moscow: Publishing House "Kompaniia p.m. Office", 190 p. [In Russian]. 
DoD. USA. (2014). Department of Defense Risk, Management Guide for Defense Acquisition Programs. 7th Edition (Interim Release) December 2014. Office of the Deputy Assistant Secretary of Defense for Systems Engineering, (pp. 6-11). Washington, D.C. Retrieved from: http://acqnotes.com/wp-content/uploads/2014/09/DoDRisk-Mgt-Guide-v7-interim-Dec2014.pdf

Edronova, V. N., \& Kavinov, A. A. (2005). The system of indicators for monitoring the sustainability of the regional financial system. Finance and Credit, 19, 4-12. [In Russian].

Fatrell, R. T., Shafer, D. F., \& Shafer, L. I. (2003). Software project management: Achieving optimal quality with minimal cost. (Trans. from English). Moscow: Williams Publishing House, 1136 p. [In Russian].

Galitsyn, V. K. (2001). Models and technologies of monitoring systems in the economy. Abstract of Doctoral Dissertation for Economic Sciences (08.03.02 - Economic-Mathematical Modelling). Kyiv: Kyiv National University of Economics, 31 p. [In Ukrainian].

Grytsiuk, Yu. I., \& Leshkevych, I. F. (2017). The Problems of Definition and Analysis of Software Requirements. Scientific Bulletin of UNFU, 27(4), 148-158. https://doi.org/10.15421/40270433

Heckerman, D. (1995). A Tutorial on Learning With Bayesian Networks. Microsoft Research. Technical Report, $124 \mathrm{p}$.

Hrytsiuk, Yu. I. (2018). Analysis of Software Requirements: Tutorial. Lviv: Publishing House of Lviv Polytechnic, 460 p. Retrieved from:

https://192.168.253.4/Research/TrainingAidsEdit.aspx?id=11750. [In Ukrainian].

Hrytsiuk, Yu. I., \& Buchkovska, A. Yu. (2017). Visualization of the Results of Expert Evaluation of Software Quality Using Polar Diagrams. Scientific Bulletin of UNFU, 27(15), 137-145. https://doi.org/10.15421/40271025

Hrytsiuk, Yu. I., \& Dalyavskyy, V. S. (2018). Using Petal Diagram for Visualizing the Results of Expert Evaluation of Software Quality. Scientific Bulletin of UNFU, 28(9), 95-104. https://doi.org/10.15421/40280919

Hrytsiuk, Yu. I., \& Nemova, E. A. (2018). Peculiarities of Formulation of Requirements to the Software. Scientific Bulletin of UNFU, 28(7), 135-148. https://doi.org/10.15421/40280727

Hrytsiuk, Yu. I., \& Zhabych, M. R. (2018). Risk Management of Implementation of Program Projects. Scientific Bulletin of UNFU, 28(1), 150-162. https://doi.org/10.15421/40280130

Hugin Expert. (n.d.). System for Building Bayes Systems. Retrieved from: http://www.hugin.com. [In Russian].

ISO/IEC 12207: 2008. Systems and software engineering - Software life cycle processes.

ISO/IEC 33001: 2015. Information technology - Process assessment.

Ivanko, S. (2008). Vnedrenie avtomatizirovannoi sistemy upravleniia organizatciiami. Korporativnye sistemy, 1, 20-25. [In Russian].

Johnson, D. L., \& Tennessee, N. (2006). Risk Management and the Small Software 1. Project.

Kastellani, K. (1982). Avtomatizatciia resheniia zadach upravleniia. Moscow, 472 p. [In Russian].

Kolesnikov, G. O. (2007). Manager dictionary: dictionary. Kyiv: Professional, 288 p. [In Ukrainian].

Kovalev, V. (n.d.). Problemy vnedreniia korporativnykh sistem. Retrieved from: http://www.infocity.kiev.ua/other/content/other061.phtml. [In Russian].

Kulikova, E. E. (2008). Upravlenie riskami. Innovatcionnyi aspekt. Moscow: Publishing House "Berator-pablishing", 224 p. [In Russian].

Kuzminykh, V. O., Khaustov, D. V., \& Korostelov, Ye. Yu. (2010). Analiz ryzykiv u korporatyvnii systemi upravlinnia proektamy. Reiestratsiia, zberihannia i obrobka danykh, 12(3), 99-107. [In Ukrainian].

Leonenkov, A. (2003). Nechetkoe modelirovanie $v$ srede MATLAB $i$ fuzzyTech. Sankt-Petersburg: Publishing House "BKhV-Peterburg", 736 p. [In Russian].
Lipaev, V. V. (2005). Analiz i sokrashhenie riskov proektov slozhnykh programmnykh sredstv. Moscow: Publishing House "Sinteg", 208 p. [In Russian].

Maksimov, V. I., \& Nikonov, O. I. (2004). Modelirovanie riska i riskovykh situatcii : uchebn. posob. Ekaterinburg : Publishing House GOU VPO UGTU - UPI, 82 p. [In Russian].

Mamedova, T. A. (2005). Model risk-menedzhmenta v INTERNETkompanii. Retrieved from: http://masters.donntu.org/2005/fvti/Mamedova/library/doc 2.htm. [In Russian].

Morhun, I. A. (2011). Metod ekspertnoi otsinky yakosti prohramnoho zabezpechennia. Inzheneriia prohramnoho zabezpechennia: mater. Mizhnar. nauk.-prakt. konf. aspirantiv i studentiv, 2(6), 33-37. Vinnytsia. Retrieved from: http://jrnl.nau.edu.ua/index.php/IPZ/article/view/3086. [in Ukrainian].

Mykhailovska, O. V. (2008). Operatsiinyi menedzhment: navch. posibnyk. Kyiv: Konkord, 550 p. [In Ukrainian].

Ostrovyj, M. V., Krasovskyj, M. V., \& Grybynchuk, V. I. (2015). Method of risk management in software development. Intelligent technologies in system programming: a collection of materials of the 4th All-Ukrainian Scientific and Practical Conference of Young Scientists and Students, (pp. 1-7), April 22-24, Khmelnitsky, Ukraine. Khmelnytsky: Publishers of KhNU, 256 p. [In Ukrainian].

Paulk, M. C., \& Curtis, B. (2001). The Capability Maturity Model: Guideline for Improving the Software Process. Carnegie Mellon University, $434 \mathrm{p}$.

Plisetsky, D. E. (2004). Monitoring system of the financial sector of the economy. Banking, 9, 6-11. [In Russian].

Pozhar, O. M. (2009). The mechanism for monitoring interest rate risk in its management system. Problems and prospects of development of the banking system of Ukraine, 24, 334-340.

Sheptur, A. A., \& Hrytsiuk, Yu. I. (2018). Establishing risk management functions for program projects implementation. The Potential of Modern Science (Part I): Materials of the III International Scientific and Practical Conference, (pp. 53-56), November 10-11, Kyiv, Ukraine. Kyiv: ICND, 76 p. [In Ukrainian].

Shkvir, V. D., Zahorodnii, A. H., \& Vysochan, O. S. (2007). Informatsiini systemy i tekhnolohii v obliku (3d ed.). Kyiv: Znannia, 439 p. [In Ukrainian].

Singaevskaia, G. I. (2008). Upravlenie proektami v Microsoft Project. Moscow: Dialektika, 800 p. [In Russian].

Sobol, I. M. (1972). Metod Monte-Karlo. Moscow: Publishing House "Nauka", 68 p. [In Russian].

Sommervill, I. (2002). Software Engineering. Sankt-Petersburg: Williams Publishing House, 624 p. [In Russian].

SWEBOK. (2004). Guide to the Software Engineering Body of Knowledge. A project of the IEEE Computer Society Professional Practices Committee. Washington IEEE, $204 \mathrm{p}$.

Terekhov, S. A. (2003). Introduction to Bayesovs Network. Moscow: Publishing House MIFI, 188 p. [In Russian].

Ustenko, S. V. (2003). Use of monitoring and controlling in the implementation of a rating management economic object. Formation of market relations in Ukraine, 11, 101-107. [In Ukrainian].

Voronin, A. N., Ziatdinov, Yu. K., \& Kulinskii, M. V. (2011). Mnogokriterialnye zadachi: modeli i metody: monografiia. Kiev: NAU, 348 p. [in Russian].

Williams, R. C., Pandelios, G. J., \& Behrens, S. G. (1999). Software Risk Evaluation (SRE) Method Description.

Zhabych, M. R., \& Hrytsiuk, Yu. I. (2018). Management of software projects and risks of their implementation. Risks of Instability: Security and Management: a collection of materials for an interdisciplinary scientific and practical conference, (pp. 16-22), March 16, Kyiv, Ukraine. Kyiv: Yudina L. I., 71 p. Retrieved from: http://futurolog.com.ua/publish/8/Zbirnyk.pdf. [In Ukrainian].

Zyl, S. (2010). Design, Development and Analysis of Real-time Software Systems. Sankt-Petersburg: Publishing House "BKhV-Peterburg", 336 p. [In Russian]. 


\section{ФОРМАЛИЗАЦИЯ ПРОЦЕССА УПРАВЛЕНИЯ РИСКАМИ РАЗРАБОТКИ} ПРОГРАММНОГО ОБЕСПЕЧЕНИЯ

Разработан подход к формализации процесса управления рисками разработки программного обеспечения (ПО), позволяющий идентифицировать и оценить неблагоприятные условия при реализации этапов программного проекта, а также делает возможным разработку стратегий и тактик их предсказания, восприятия и преодоления негативных последствий от их проявления. Установлено, что управление рисками разработки ПО нужно рассматривать как процесс, который позволяет определить особенности такого управления, основные категории имеющихся рисков, риск-ориентированный подход к внедрению мер по их предотвращению и обезвреживанию. Уточнены подходы к идентификации рисков разработки ПО, их основательного анализа, планирования и мониторинга, что позволило поменять модель деятельности проектного менеджмента в целом и изменить модель поведения руководителя проекта в частности на различных этапах реализации программного проекта. Усовершенствована методика определения возможных источников появления рисков разработки ПО и идентификации потенциальных рисковых событий, сформировано структурированное множество имеющихся рисков реализации программных проектов и разработаны их формализованные модели для проведения соответствующих расчетов.

Разработана методика определения вероятностей наступления потенциальных рисковых событий в соответствующих их множествах, предложен подход к распределению стоимости реализации программного проекта по этим множествами вообще и потенциальным рисковым событиям в частности, определены доли и величины возможных убытков от наступления рисковых событий, установлены приоритеты их смягчения и ранжирования. Уточнение меры по предотвращению или обезвреживанию рисков разработки ПО, усовершенствована методика определения вероятности уменьшения или устранения различных рисковых событий, определены правила и политика реализации программного проекта, разработаны их формализованные модели.

Ключевые слова: программное обеспечение; рисковые события; негативные последствия; потенциальные проблемы; вероятность наступления неблагоприятных событий; приемлемый (допустимый) риск; риск возникновения потенциальных опасностей.

Yu. I. Hrytsiuk, V.S. Dalyavskyy Lviv Polytechnic National University, Lviv, Ukraine

\section{FORMALIZATION OF THE RISK MANAGEMENT PROCESS OF SOFTWARE DEVELOPMENT}

An approach to formalizing risk management process of software development (software). The approach allows us to identify and assess the adverse situations during the implementation phases of a software project makes it possible to develop a strategy and tactics of their predictions, perception and overcoming the negative consequences of their manifestations. It was found that the risk management software development should be viewed as a process that allows you to determine the characteristics of the management, the main categories of existing risks, risk-based approach to the implementation of measures for their prevention and decontamination. Also, this process makes it possible to determine the acceptable level of risk for the successful completion (failure) of a software project IT-company. Refined approaches to identifying risks of software development, a thorough risk analysis methods, planning and monitoring. This allowed to change business model of project management in general, and change behaviour in a particular project manager at various stages of the software project. Improved method of determining the possible sources of the risks of software development and identification of potential risk events. Formed structured set of existing risks and the implementation of software projects developed their formal model for the corresponding calculations. Improved method of determining the possible sources of the risks of software development and identification of potential risk events. Formed structured set of existing risks and the implementation of software projects developed their formal model for the corresponding calculations. Improved method of determining the possible sources of the risks of software development and identification of potential risk events. Formed structured set of existing risks and the implementation of software projects developed their formal model for the corresponding calculations.

The technique of determining the probabilities of potential risk events in their respective sets. An approach to the allocation of the cost of implementing a software project to these sets in general and the potential risk events in particular. Identified part and the amount of possible losses from the risk events, prioritized mitigation and ranking. Analyzed to identify potential risk events software development, these events are ranked according to priority response, developed their formal models. Clarification of the measures to prevent or neutralization of the risks of software development, improved method of determining the likelihood of reducing or eliminating the various risk events. Defined rules and policies of the application project, implemented the principles of risk management software development, and developed their formal models. The notion of "software development risk monitoring", the specific features of its implementation in the IT-companies from an organizational point of view. Defined as a monitoring system with a set of elements such as target object, subject and implementation mechanism, and also set its security subsystem - a technical, and regulatory information.

Keywords: software; risk events; negative consequences; potential problems; probability of occurrence of adverse events; acceptable (valid) risk; risk of potential hazards. 